\title{
BIOSYNTHETIC DETERMINATION WITH RADIOACTIVE SULFUR OF TURN-OVER RATES OF VARIOUS PLASMA PROTEINS IN NORMAL AND CIRRHOTIC MAN ${ }^{1,2}$
}

\author{
By WADE VOLWILER, ${ }^{3}$ PATRICK D. GOLDSWORTHY, MARION P. MACMARTIN, \\ PATRICIA ANN WOOD, IAN R. MACKAY, 4 AND KENNETH FREMONT-SMITH
}

\author{
(From the Department of Medicine, University of Washington, Seattle, Wash.)
}

(Submitted for publication December 17, 1954; accepted March 24, 1955)

Data concerning the life-span of various human plasma proteins are yet meager. Methods have been difficult and data often uncertain of interpretation. Approximations have depended chiefly upon determining the rate of release of isotopic labels from protein molecules. Both in vitro chemical incorporation of isotope $\left(\mathrm{I}^{131}\right)$ and in vivo biosynthetic labeling $\left(\mathrm{N}^{15}, \mathrm{~S}^{35}\right)$ have been employed.

In this laboratory, an effort has been made to measure the "life-duration" of total serum proteins, albumin, fibrinogen, beta- 1 lipoproteins, and gamma globulins in normal and cirrhotic man. Biosynthetic introduction of the radioisotope tag $\left(\mathrm{S}^{35}\right)$ has been chosen rather than chemical labeling so as to avoid any alteration in biologic life-span which might result from chemical labeling procedures. Two types of experiments have been carried out : measurement of rate of isotope loss in plasma protein fractions (I) after feeding $\mathrm{S}^{\mathbf{3 5}}$ labeled cystine and (II) following transfusion of plasma previously labeled by a normal human donor fed $\mathrm{S}^{35}$ cystine. A very considerable effort has been made to utilize the newer and more precise chemical and physical methods in separating the various plasma proteins from small blood samples. Relatively homogeneous protein fractions have been isolated for isotope analysis. In a few experiments, simultaneous observations have been made upon rates of albumin decay with both

\footnotetext{
1 This investigation was supported by research grants from the National Institute of Arthritis and Metabolic Diseases of the National Institutes of Health, U. S. Public Health Service (A-173); the John and Mary R. Markle Foundation; the A. H. Robins Company, Richmond, Va.; and funds for Research in Biology and Medicine accruing through Initiative 171 of the State of Washington.

2 Presented in part before the annual meeting of the Western Society for Clinical Research, January 29, 1954. 3 John and Mary R. Markle Scholar.
}

4 A. H. Robins Research Fellow in Gastroenterology. biosynthetic $\left(\mathrm{S}^{35}\right)$ and chemical ( $\left.\mathrm{I}^{131}\right)$ labeling methods. Studies have been conducted simultaneously in normal subjects and in subjects with advanced portal cirrhosis having gross abnormalities of plasma proteins, with hope of discovering if differences are present in the biologic life-span of plasma protein components.

\section{METHODS}

\section{Subjects Chosen for Study}

\section{Normal subjects}

Individuals were male laboratory colleagues or medical students under 36 years. All were stable in weight, had good health, and showed normal bromsulfalein excretion, thymol turbidity tests and serum electrophoretic patterns. Regularity of the individual's usual high protein diet and working hours was maintained throughout the period of study. Serum total protein, albumin concentrations, hematocrit, and body weight remained constant during the period of observations.

\section{Cirrhotic subjects}

These subjects were selected for study as being in an advanced stationary phase of portal cirrhosis. The majority had been confined to the chronic disease unit of King County Hospital for many weeks before commencing observations. Although gross alteration in the concentration of various plasma proteins with marked hypoalbuminemia was present in most, nearly all were edema-free at the time of study. Serum protein concentrations, hematocrit, and body weight were constant during the period of study. All cirrhotic subjects except one ${ }^{5}$ were confined to the Research Metabolic Ward throughout the period of observation, and all were maintained on constant diet (calories to maintain weight, protein $90 \mathrm{gm}$., fat 90 to $130 \mathrm{gm}$., sodium restricted as necessary to avoid edema). Detailed data of each defining the severity of cirrhosis, body weight, and caloric intake ${ }^{B}$ are given in Table I; brief case summaries appear in the Appendix.

\footnotetext{
5 Subject 11 , studied in chronic disease unit.

- Though variations in caloric and protein intake relative to body weight occurred, these were not considered to be of the magnitude shown to influence significantly rates of plasma protein metabolism (1).
} 
Isotope Preparation and Administration

Radioactive sulfur

Dose and form of $\mathrm{S}^{35}$ given to each subject are shown in Table II. In early experiments, chemically synthesized $\mathrm{S}^{35}$-labeled dl-cystine ${ }^{7}$ was used. In later observations, $\mathrm{S}^{35}$-labeled 1-cystine ${ }^{8}$ was employed; this was prepared by the action of yeast upon labeled sulfate, with subsequent chromatographic isolation of the amino acid.

Oral administration of cystine: The dose of amino acid, contained in 50 to $150 \mathrm{ml}$. of very dilute hydrochloric acid, was taken by the subject intermittently during breakfast.

Plasma transfer: Normal donors compatible for plasma transfer to the selected recipients were bled in the fasting state 20 hours after oral administration of $\mathrm{S}^{35}$-labeled cystine, utilizing the facilities of the King County Central Blood Bank.9 Approximately $825 \mathrm{ml}$. of whole blood were collected in two bottles, each containing $120 \mathrm{ml}$. standard acid citrate dextrose ${ }^{10}$ solution. After storage at $4^{\circ} \mathrm{C}$. for 1 hour, the bottles were centrifuged, and the plasma separated into two labeled-plasma units of approximately equal volume. In cases where the recipient was of other than the major blood group of the donor, though agglutinin titres were very low, $10 \mathrm{ml}$. Sharp \& Dohme Solution Blood Group A and B Specific (Witebsky) Substances were added to a plasma unit. Duplicate plasma units were promptly transfused (within 3 hours of bleeding) into a normal and a cirrhotic subject. Erythrocytes were resuspended in saline and returned to the donor.

\section{Radioactive iodine ( $\Gamma^{\mathbf{1 3 1}}$ )}

The iodinated human albumin preparation 11 was reported to contain 1 to 2 iodine atoms per molecule of protein, with a concentration of $10 \mathrm{mg}$. protein and $45 \mu_{\mathrm{C}}$ $\mathrm{I}^{131}$ per $\mathrm{ml}$. Exactly $102.25 \mu \mathrm{c}$ were injected with rinsing into the rubber tubing of the intravenous set conveying $\mathrm{S}^{35}$-labeled plasma (or saline) to each subject. Thyroid uptake of radioactive iodine was blocked by administering a saturated solution of potassium iodide, 10 drops three times daily, throughout the period of the study.

\section{Separation of Plasma Protein Components}

\section{Collection of blood}

About three times weekly, 90 to $100 \mathrm{ml}$. blood were drawn in the fasting state. Thirty $\mathrm{ml}$. were used for fibrinogen preparation, and serum was obtained from the

${ }^{7}$ Generously provided by Dr. Harold Tarver, Dept. Physiological Chemistry, University of California.

8 Chiefly obtained from Dr. Harold Tarver; some furnished by Abbott Laboratories.

9 The authors are grateful for the assistance of Dr. Richard S. Czajkowski and Mr. Soren Juul.

10 Trisodium citrate $22.0 \mathrm{gm}$., citric acid $8.0 \mathrm{gm}$., dextrose $24.5 \mathrm{gm}$. per liter.

11 Abbott Laboratories, administered within four days of iodination.

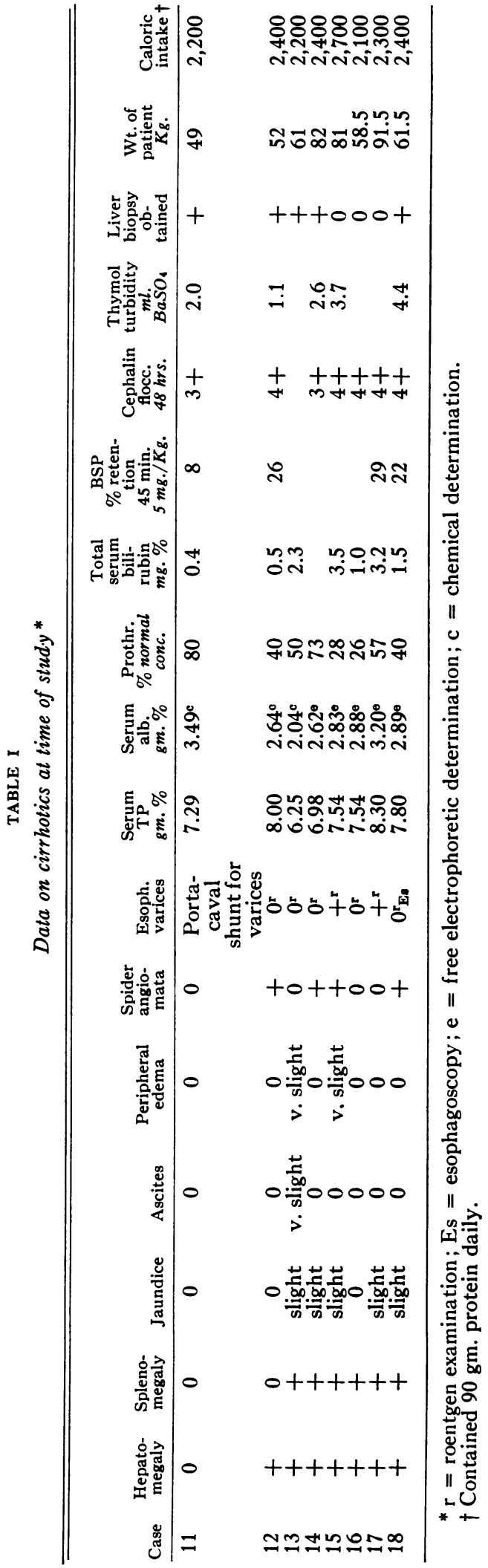


TABLE II

Isotope dosage and excretion

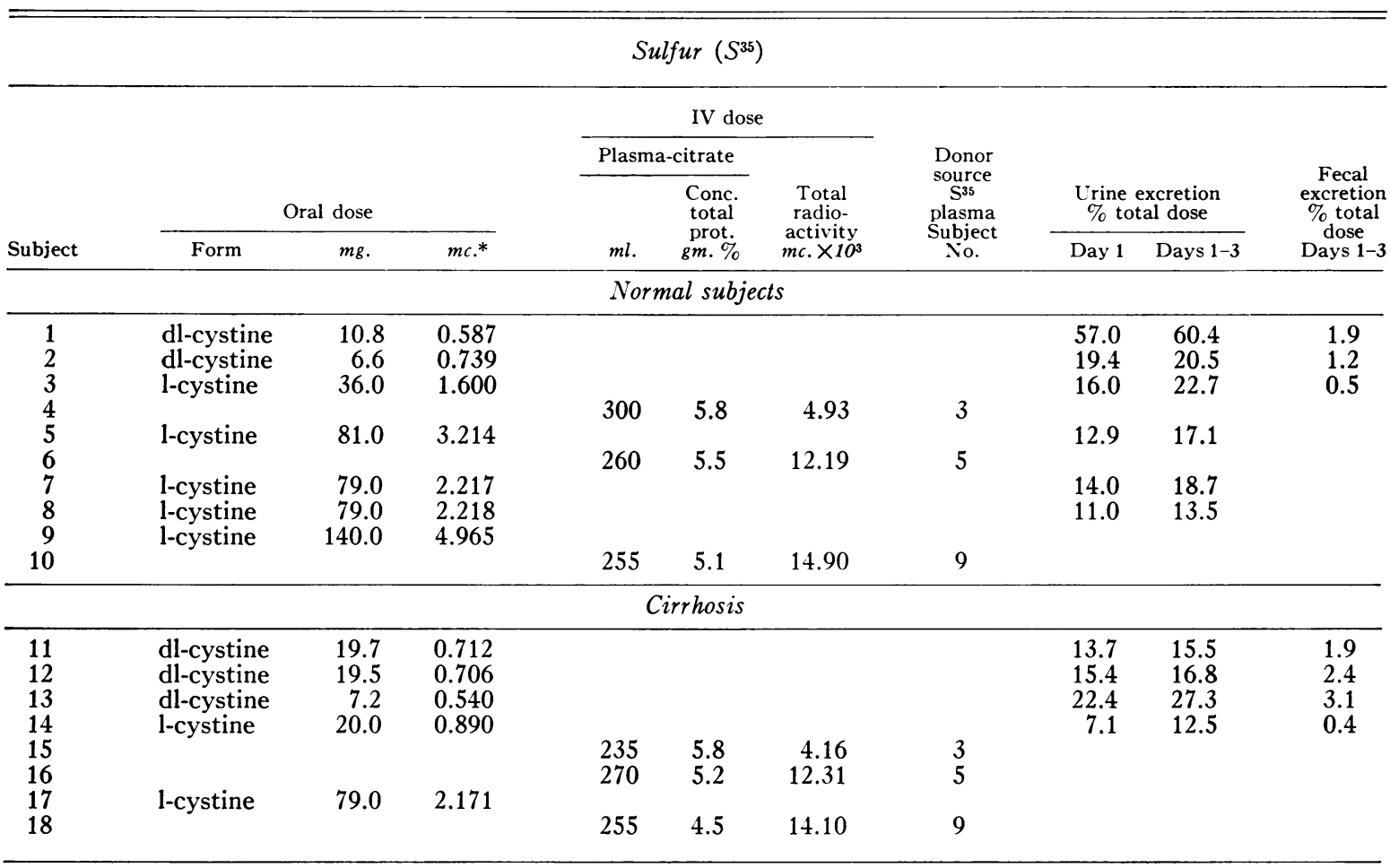

Iodine $\left(I^{131}\right)$

(Each subject received IV $2.7 \mathrm{mg}$. human serum albumin containing $102.25 \mu \mathrm{c} \mathrm{I}^{131 *}$ )

\begin{tabular}{ccc}
\hline & \multicolumn{2}{c}{$\begin{array}{c}\text { Crinary excretion } \\
\% \text { total dose }\end{array}$} \\
\cline { 2 - 4 } Subject & Day 1 & Days 1-3 \\
\hline 9 & Normal & 20.2 \\
\hline 10 & 8.2 & 20.9 \\
\hline & 8.8 & 18.1
\end{tabular}

* Approval of this dosage was obtained from the Subcommittee on Human Applications of the Atomic Energy Commission.

remainder after allowing it to clot for 1 to 2 hours. One part of ACD solution (2) was added to three parts of serum; this serum solution was then allowed to stand overnight at 4 to $5^{\circ} \mathrm{C}$.

\section{Fibrinogen}

Employing the general method of Surgenor, Alexander, Goldstein, and Schmid (3), calcium was removed from $30 \mathrm{ml}$. of blood by passage over sodium cycle Dowex-50 cation-exchange resin. One-tenth volume of barium sulfate was suspended in the plasma, which was then cooled to 0 to $1^{\circ} \mathrm{C}$. After stirring for 10 minutes, the barium sulfate was removed. The fibrinogen was then precipitated by diluting the plasma with an equal volume of acetate-ethanol reagent 12 to give a final $\mathrm{pH}$ of 6.9 and ethanol concentration of 6 per cent. After standing one hour at 4 to $5^{\circ} \mathrm{C}$., the precipitate was separated by centrifugation at $0^{\circ} \mathrm{C}$., washed with $5 \mathrm{ml}$. cold 6 per cent ethanol in $\mathrm{pH} 6.8$ phosphate buffer (ionic strength 0.01 ), and recentrifuged. This washing procedure was repeated three times.

\section{Albumin}

ACD serum was carried through the Cohn Method 10 fractionation (2) to obtain Fraction IV $+\mathrm{V}$. This

12 The quantity of $\mathrm{pH} 4$ acetate buffer $(0.16 \mathrm{M}$ sodium acetate, $0.08 \mathrm{M}$ acetic acid) to be added was determined by titration of a plasma aliquot to $\mathrm{pH} 6.9$. 
product was subjected to further differential precipitation and extraction in buffered ethanol solutions at $-5^{\circ} \mathrm{C}$., as devised by Batchelor and Brown (4) to yield Fraction $\mathrm{V}$; this allowed separation and discard of a glycoprotein by means of differential solubility.

\section{Beta-1 lipoproteins}

ACD serum was fractionated by the Cohn Method 10 (2) to obtain Fraction I + III. In the later experiments, this sample was then subjected to preparative ultracentrifugation in low and high density salt solutions, in accord with the general plan of Lindgren, Elliott, and Gofman (5): The Cohn I + III paste from $15 \mathrm{ml}$. of serum was dissolved in $9 \mathrm{ml}$. cold $0.1 \mathrm{M}$ sodium chloride (density $1.004^{13}$ ), and centrifuged in a $10.5 \mathrm{ml}$. capacity lusteroid tube at $4^{\circ} \mathrm{C}$. for 12 hours at $40,000 \mathrm{rpm}$ (Model L Spinco Ultracentrifuge, size 40 head). The top $7 \mathrm{ml}$. of fluid which contained chylomicrons, lipids, and lipoproteins of $S_{f}$ values approximately 17 to 70 was discarded and the walls of the tube wiped clean. To the residual solution was added, with stirring, $7 \mathrm{ml}$. cold saline-glycine reagent, density $1.090^{14}(0.3 \mathrm{M}$ sodium chloride, $3.38 \mathrm{M}$ glycine) to obtain a final density of $1.064 .^{15}$ After centrifugation for 12 hours at $4^{\circ} \mathrm{C}$. and $40,000 \mathrm{rpm}, 1$ to $2 \mathrm{ml}$. of the floating viscous yellow layer plus saline was carefully removed with a glass capillary or short-beveled needle and syringe from the interface of the tube wall, lipoprotein and air. This material was presumed to contain lipids and lipoproteins of $S_{\mathbf{f}}$ values approximately 2 to 17 , thus lipoproteins migrating electrophoretically with the beta globulins and of density greater than 1.004 but less than 1.064. This lipoprotein solution was then dialyzed against running tap water for 6 hours before oxidizing to inorganic sulfate.

\section{Gamma globulins}

ACD serum was separated by the Cohn Method 10 (2) to obtain Fraction II. For subjects 9, 10, and 18, a slight modification suggested by Russ (6) was employed; this attempted more complete removal of beta globulins by increasing their solubility through use of larger volumes of reagents ( 7 plasma volumes instead of 5 ). In a few experiments, Fraction II was subjected also to further purification by a modification of the starch zone electrophoresis method of Kunkel and Slater (7), using a pH 9.0 phosphate buffer, ionic strength 0.1 ; eluted protein from the trailing half of the gamma globulin zone, presumed to be free of beta globulins, was analyzed for sulfur specific activity. Neither of these modifica-

13 At $23^{\circ} \mathrm{C}$.

14 At $23^{\circ} \mathrm{C}$.

15 Calculated at $23^{\circ} \mathrm{C}$. without considering the effect of the lipoprotein; at $5^{\circ} \mathrm{C}$. this density was determined to be 1.069 . For subjects 9,10 , and 18 , sufficient reagent was added to obtain a final measured density of 1.064 at $23^{\circ} \mathrm{C}$; the sample was then made to volume by adding reagent of same density. tions, however, appeared to alter the character of the isotope data finally obtained.

\section{Appraisal of Homogeneity of Protein Fractions}

One or two samples of each fraction from most experimental subjects were analyzed for electrophoretic homogeneity. The electrophoresis apparatus (PerkinElmer Model 38) was used with diethyl-barbiturate buffer, $\mathrm{pH}$ 8.6, ionic strength 0.1 and sample protein concentrations of 1 to 1.5 per cent. Photographs were taken with the knife-edge and Schlieren lens-scanning system. Analyses of enlarged electrophoretic patterns were made by dropping perpendiculars to the base line from the low point between peaks. The pattern areas were then obtained by taking the mean of the planimeter-measured areas beneath the upper and lower contour edges of the descending limb patterns (8). The $\beta$ anomaly was analyzed by measuring the area above the base line and subtracting from it the area below the base line. Per cent electrophoretic homogeneity was found as follows : albumin : normal 85.4 to 100.0 (average 91.9 ), cirrhosis 79.6 to 91.1 (average 85.6 ); $\beta_{1}$ lipoprotein : normal 87.9 to 100.0 (average 94.2 ), cirrhosis 80.3 to $100 . \Omega$ (average 90.1) ; fibrinogen: normal 69.6 to 100.0 (average 81.7 ), cirrhosis 56.3 to 88.8 (average 77.5 ) ; $\gamma$ globulin: ${ }^{16}$ normal 81.2 to 89.1 (average 84.7 ), cirrhosis 77.8 to 94.5 (average 88.7 ). Electrophoretic mobility of fibrinogen peaks ranged from -2.0 to -2.6 (average -2.3 ) $\mathrm{cm}^{2}$ volt $^{-1}$ sec. $^{-1} \times 10^{-5}$.

Ultracentrifugal analyses of a number of beta-1 lipoprotein preparations were made $\mathbf{1 7}$ in the analytical ultracentrifuge (Spinco Model E) equipped with a diagonal bar, cylindrical lens Schlieren optical system and analytical rotor (type A) ; this was operated at $24^{\circ} \mathrm{C}$., $52,640 \mathrm{rpm}$ with an acceleration time of 6 minutes and camera exposures taken at $0,8,16,24,32$, and $40 \mathrm{~min}$ utes. In each case only one discrete migrating boundary was observed (Figure 1) with the flotation constant shown in Table III; however, in a few instances a very small amount of a slightly faster component could be detected on the leading edge of the major boundary.

The beta-1 lipoproteins were further characterized by the chemical analyses summarized in Table III. Total and free cholesterol 18 were determined by the method of Sperry and Webb (12), phospholipid 18 by a modification of the combined methods of Whitehorn (13) and Fiske and Subbarow (14), and nitrogen as described below.

The purity of the fibrinogen preparations, measured as clottable protein by Morrison's procedure (15), was found to be 55 to 63 per cent.

16 Whereas the major peak of other fractions was always symmetrical, the gamma peak was usually asymmetric, with a steeper gradient on the trailing edge.

${ }^{17}$ Kindly performed by Mr. Roger Wade of the Department of Biochemistry.

18 For these determinations we are indebted to Mrs. Della Ramsden of the Department of Pathology. 


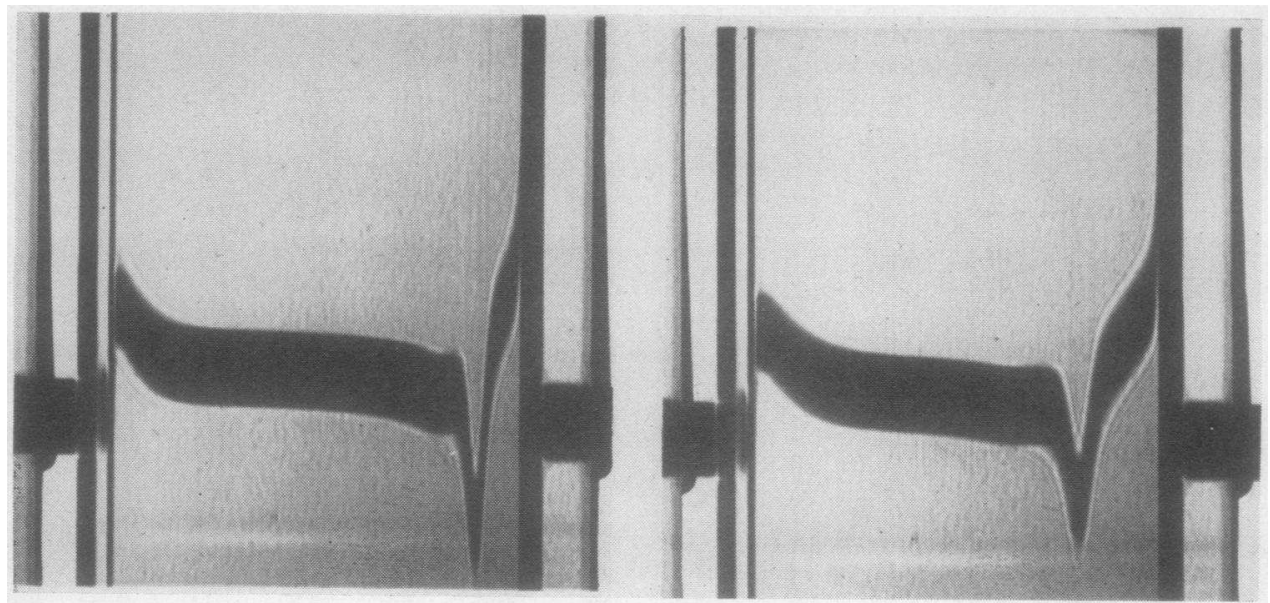

Fig. 1. Ultracentrifugal Flotation Pattern of Representative $\beta_{1}$ Lipoprotein Sample (Subject 17), Exposures at 16 and 32 Minutes

Sample centrifuged at $52,640 \mathrm{rpm}$ at $25^{\circ} \mathrm{C}$. in sodium chloride-glycine solution of approximate density 1.064 .

\section{Preparation of Samples for Isotope Analysis $S^{\mathrm{s5}}$ analysis}

Plasma proteins: Protein sulfur was first oxidized to inorganic sulfate by the nethod of Pirie (16) and then crystallized as the benzidine sulfate (17). Protein samples of 50 to $150 \mathrm{mg}$. were oxidized with $5 \mathrm{ml}$. Pirie's reagent by being warmed slowly to 280 to $300^{\circ} \mathrm{C}$. and kept at this temperature for 18 hours. After removal of the residual perchlorate by heating, $1 \mathrm{ml}$. conc. $\mathrm{HCl}$ was added and the sample was reheated at $300^{\circ}$ in the air bath until dry. After cooling, $3 \mathrm{ml}$. water and 3 drops of $1 \mathrm{~N} \mathrm{HCl}$ were added; any precipitate remaining after slight warming was filtered off. Two $\mathrm{ml}$. of benzidine dihydrochloride reagent ( 2 per cent in $0.2 \mathrm{~N} \mathrm{HCl}$ ) were added and the solution was then kept at $4^{\circ} \mathrm{C}$. for 24 hours. When the sample was small, crystallization was aided by the addition of ethanol to 50 per cent concentration, shaking and reducing the temperature to 0 to $-5^{\circ} \mathrm{C}$.

Approximately $4 \mathrm{mg}$. quantities 19 of benzidine sulfate were collected (sample diameter $21 \mathrm{~mm}$.) on Whatman

19 These varied from 0.18 to $1.82 \mathrm{mg}$. benzidine sulfate per $\mathrm{cm}^{2}$ sample surface. The smaller amounts were from $\beta_{1}$ lipoprotein fractions, the highest from albumin. The amounts of plasma or serum required to furnish benzidine sulfate samples of adequate size varied widely according to the specific protein fraction, and depended chiefly upon the plasma concentration and the sulfur content of the protein component. The benzidine sulfate plated upon a single planchet represented the recovered amounts of the individual proteins from the following quantities of serum or plasma: albumin 0.8 to $1.5 \mathrm{ml}$. serum, gamma globulin 1.7 to $7 \mathrm{ml}$. serum, $\beta_{1}$ lipoprotein 22 to $30 \mathrm{ml}$. serum, fibrinogen 15 to $20 \mathrm{ml}$. plasma, total protein $0.4 \mathrm{ml}$. serum. Thus, whereas duplicate samples of albumin, gamma globulin, and total protein were customarily prepared, only single planchet samples of fibrino-
42 filter paper by filtration on a stainless steel screen or sintered glass apparatus similar to that used by Tarver and Schmidt (18) and Kinsell and co-workers (19). The precipitate was washed with cold distilled water and cold 95 per cent ethanol. After drying at room temperature, the paper was mounted for counting upon a Tracerlab E-7 brass disc with ring. The total quantity of sulfur counted as benzidine sulfate was determined by titrating an aqueous solution of the benzidine sulfate (boiled frequently to remove $\mathrm{CO}_{2}$ ) with $0.01 \mathrm{~N} \mathrm{NaOH}$ using phenol red as an indicator.

Urine: Small aliquots $(0.2 \mathrm{ml}$.) of the diluted $(1: 10)$ 24-hour urine collections were evaporated and counted 20 on copper or stainless steel planchets.

Feces: Since the total isotope content of benzidine sulfate from stool samples was low, only filtered aqueous extracts of 24-hour stool samples were evaporated and counted (without self-absorption correction) on stainless steel planchets.

\section{$I^{131}$ analysis}

Serum: Two ml. samples of serum were counted in 4 $\mathrm{ml}$. screw-top glass vials.

Urine: Two ml. aliquots of 24-hour urine specimens were similarly counted. For collections made 28 to 35 days after the injection of $\mathrm{I}^{131}$ albumin, urine was concentrated 5 to 10 fold before counting.

\section{Isotope Counting}

$S^{35}$ counting

$\mathrm{S}^{35}$ activity was measured in a windowless gas-flow Geiger-Müller counter having an efficiency of 50 per cent and a background of 15 counts per minute.

gen and $\beta_{1}$ lipoprotein were obtained for each experimental point.

${ }^{20}$ Several control experiments showed that no selfabsorption correction need be applied. 
Corrections were applied to the counting data as necessary for self-absorption, coincidence (20), and decay, Day-to-day variation, and differences in instrumentation, were eliminated by counting a $\mathrm{C}^{\mathbf{1 4}}$ reference standard with all samples.

\section{$I^{131}$ counting}

$\mathrm{I}^{131}$ activity was measured in a well-type sodium iodide crystal scintillation counter having an efficiency of 28 per cent and a background of 80 to 100 counts per minute. Samples were prepared and counted in duplicate except for the concentrated urine samples.

Corrections for both day-to-day variations in counter sensitivity and isotopic decay were made by counting an $I^{131}$ standard source daily, then correcting the sample activities by a factor which was the ratio of $\mathrm{I}^{131}$ standard source initial activity to $\mathrm{I}^{131}$ standard source daily activity.

\section{Differential counting}

There was no interference of either of the isotope activities with the counting of the other. $\mathrm{I}^{131}$ was found to be completely removed from $S^{35}$ during the protein digestion and benzidine sulfate crystallization while the scintillation counter could detect only the $I^{131}$ activity of the isotope mixture.

\section{Miscellaneous Analytical Procedures}

\section{Plasma volume}

The method of Gibson and Evans (21) was used, where $5 \mathrm{ml}$. of 0.5 per cent Evans Blue dye (T-1824) 21 were injected, 4 to 6 heparinized blood samples being withdrawn between 10 and 25 minutes after dye injection. Following determination of plasma dye concentrations in a Beckman Model B Spectrophotometer (wave length $605 \mathrm{~m} \mu$ ), these data were plotted against time on linear graph paper, and the curve extrapolated to obtain zero time plasma dye concentration.

\section{Nitrogen}

Micro-Kjeldahl digestion was employed, using the mercury catalyst of Hiller, Plazin, and Van Slyke (22), followed by distillation of ammonia from the Kirk apparatus (23) into 2 per cent boric acid solution, and semimicrotitration of the distillate with standard sulfuric acid. Corrections for non-protein nitrogen were made (24).

\section{Serum total protein concentration}

The factor 6.25 was employed to convert grams of nitrogen to total protein.

\section{Albumin concentration}

Chemical determination was conducted by salting-out the globulins by the method of Reinhold, Steward, and Gilman $(25,26)$; the nitrogen of the albumin filtrate was measured by micro-Kjeldahl as described above.

\footnotetext{
21 William R. Warner \& Co.
}

\section{Plasma fibrinogen concentration}

The method of Ratnoff and Menzie (27) was modified by using the colorimetric determination of protein content described by Lowry, Rosebrough, Farr, and Randall (28). For converting tyrosine to fibrinogen concentrations, the average factor used was determined by three experiments to be 7.38 with a standard deviation from the mean of 0.14 .

\section{Serum beta-1 lipoprotein concentration}

This was roughly approximated from dried weight (9) of total sample.

\section{Experimental errors}

The errors of the various specific activities used in making half-life determinations were: (a) Plating of benzidine sulfate. Samples of less than $0.4 \mathrm{mg}$. per $\mathrm{cm}^{2}$

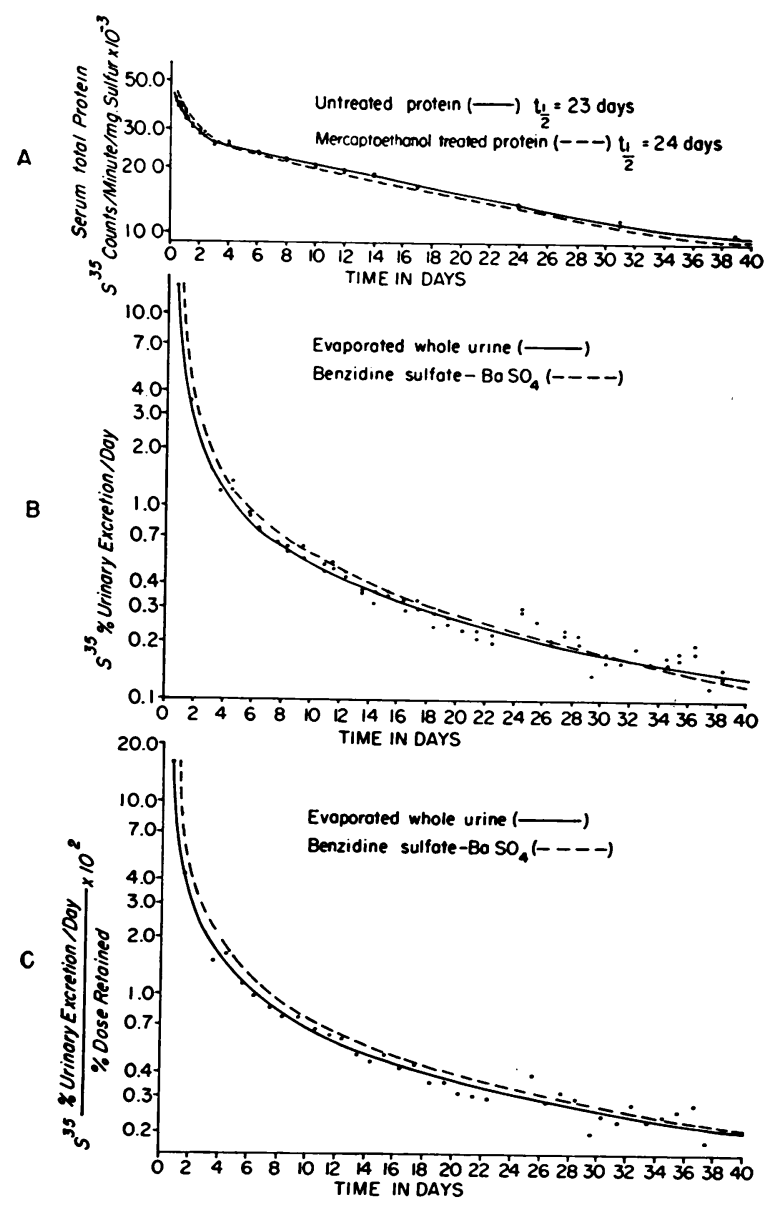

Fig. 2. Subject 7 : Studies of Urinary $\mathrm{S}^{35}$ Excretion and Stability of Protein-Bound Isotope

Daily isotope excretion shown as the broken lines in graphs $B$ and $C$ was obtained as the product of sulfur specific activity from isolated benzidine sulfate times total sulfur excreted, determined as barium sulfate. Solid lines are drawn through experimental points shown. 


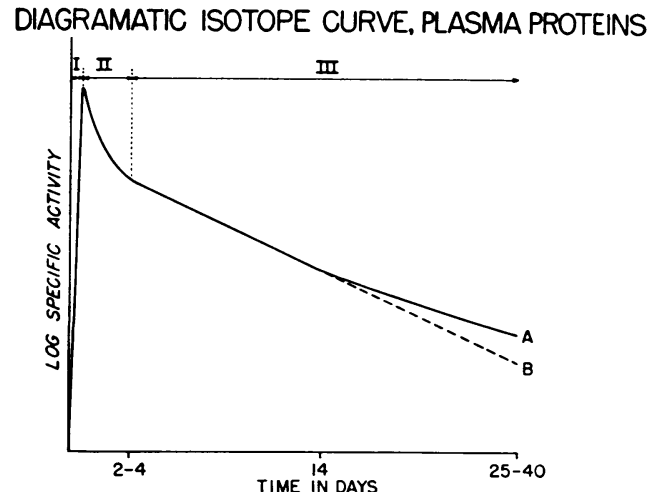

Fig. 3. Curve A: Fractions of $\beta_{1}$ Lipoprotein and Fibrinogen Obtained Following Oral Administration of $\mathrm{S}^{35}$-Labeled Cystine or after TransFUSing $\mathrm{S}^{35}$-Labeled Plasma

Curve B: Fractions of $\gamma$ Globllins Isolated Following Transfusion of $\mathrm{S}^{35}$-Labeled Plasma, and Albumin or Total Serum Proteins Obtained after Either Oral Administration of $\mathrm{S}^{35}$-Labeled Cystine or Intravenous Transfer of $\mathrm{S}^{35}$-Labeled Plasma

( $\beta_{1}$ lipoprotein samples only) could not be evenly distributed over the entire planchet surface. Since self absorption correction factors are based upon even distribution, a standard deviation from the mean of \pm 2 per cent would be introduced if the sample were to cover only 60 per cent of the planchet surface area. (b) Counting. The standard deviation from the mean of counting rates, due to the random nature of disintegration, were calculated from curves constructed from published data (20). These errors for the different specific activities on the first and last days involved in the half-life calculation were, for experiments where oral cystine was given: \pm 1 and 3 per cent for $\beta_{1}$ lipoprotein, \pm 1 per cent for other fractions; and when $\mathrm{S}^{35}$-labeled plasma was administered: \pm 3 and 9 per cent for $\beta_{1}$ lipoprotein, \pm 2 and 5 per cent for other fractions. (c) Titration of benzidine sulfate. The standard deviation from the mean was \pm 0.3 to 1.0 per cent for normal $\gamma$ globulin and all $\beta_{1}$ lipoprotein samples, but less than \pm 0.5 per cent for cirrhotic $\gamma$ globulin and all total protein and albumin samples.

Considering the above factors, the resultant standard deviation from the mean of values for half-life was determined to be \pm 1 to 2 per cent for all protein fractions following oral cystine administration. After $\mathrm{S}^{35}$-labeled plasma infusions, this standard deviation was \pm 6 per cent for $\beta_{1}$ lipoprotein and \pm 2.5 to 3.5 per cent for all other fractions. The law of least squares was applied to determine the trend of the experimental points whenever a straight line was drawn for a half-life calculation.

\section{RESULTS}

Multiple plasma protein fractions were studied in seven normal and five cirrhotic subjects fed $\mathrm{S}^{35}$ labeled cystine, and in three normal and three cirrhotic patients infused with $\mathrm{S}^{35}$-labeled plasma. Summary data concerning the form of isotope administered, dosage, and gross fecal and urine excretion in the various subjects are presented in Table II. The $\mathrm{S}^{35}$ label was excreted mainly in the urine; large proportions were lost during the first two to three days, after which excretion gradually diminished but continued for many weeks (Figure 2). The proportion of total oral dose of isotope present at 24 hours in the rapidly circulating total plasma proteins ${ }^{22}$ was: for subject 3, 4.1 per cent ; for subject 5, 5.0 per cent ; and for subject 9, 6.7 per cent.

\section{General form of isotope curve}

Although the form of the isotope concentration curves of the plasma protein fractions studied was

\section{$\beta_{1}$ LIPOPROTEIN}

SUBJECT 9

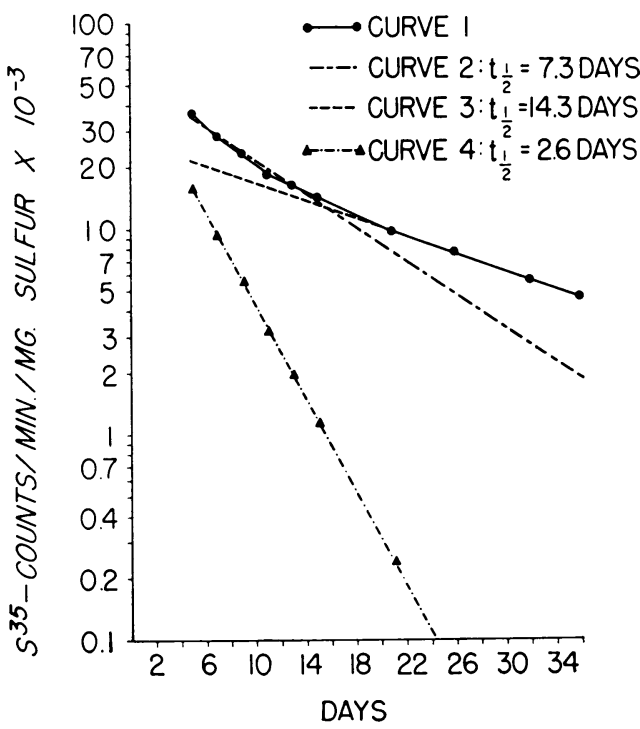

Fig. 4. Curve 1: Plot of Experimental Points Simulating Binomial Exponential Curve

Curve 2: Straight Line Drawn through Experimental Points of Days 4 to 14, Giving Apparent $t_{1 / 2}$ of Early Portion Phase III

Curle 3: Slow Exponential Component Obtained by Extrapolation of Terminal Portion of Curve

Curve 4: Fast Exponential Component Obtained by Graphic Subtraction of Curve 3 from Initial Portion of Curve 1

22 Those contained in the plasma space, as defined with Evans blue dye. 


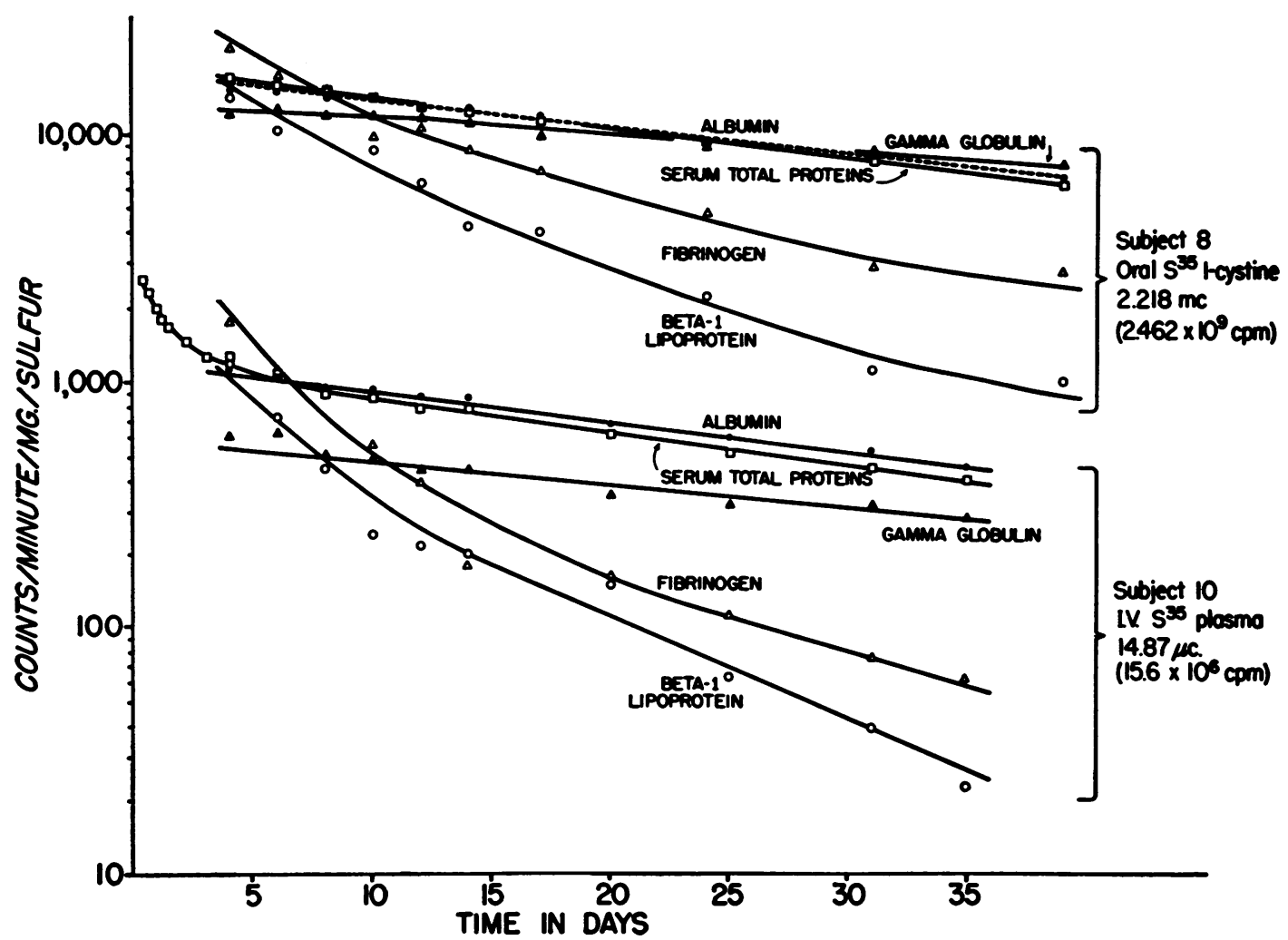

Fig. 5. Data Curves of All Protein Components Studied in a Representative Subject from Each TyPE OF EXPERIMENT Conducted

found to be similar to that previously described by others (29-31), certain consistent differences between specific fractions were noted. The plot of the log of specific activity of the sulfur against time for each protein fraction could be divided into the three general phases shown in Figure 3: Phase I-Formation and release of labeled plasma proteins into the vascular system. Following oral administration of $\mathrm{S}^{35}$-labeled cystine, the duration of this phase varied from 16 to 22 hours. This phase was absent following the intravenous administration of labeled plasma. Phase IIEquilibration and dilution of labeled plasma proteins with unlabeled proteins of the body's fluid

\section{ORGANIC SULFUR POOL}

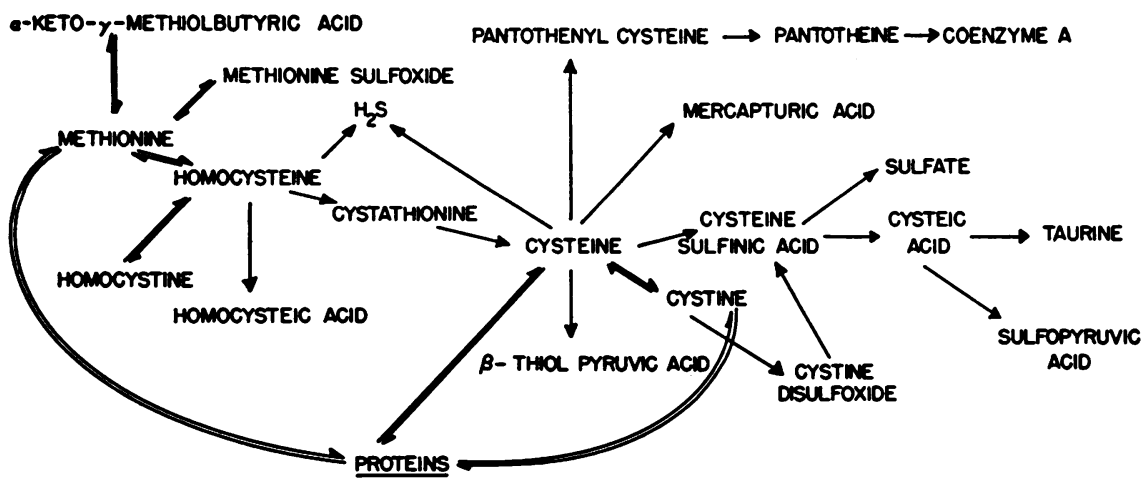

Figure 6 


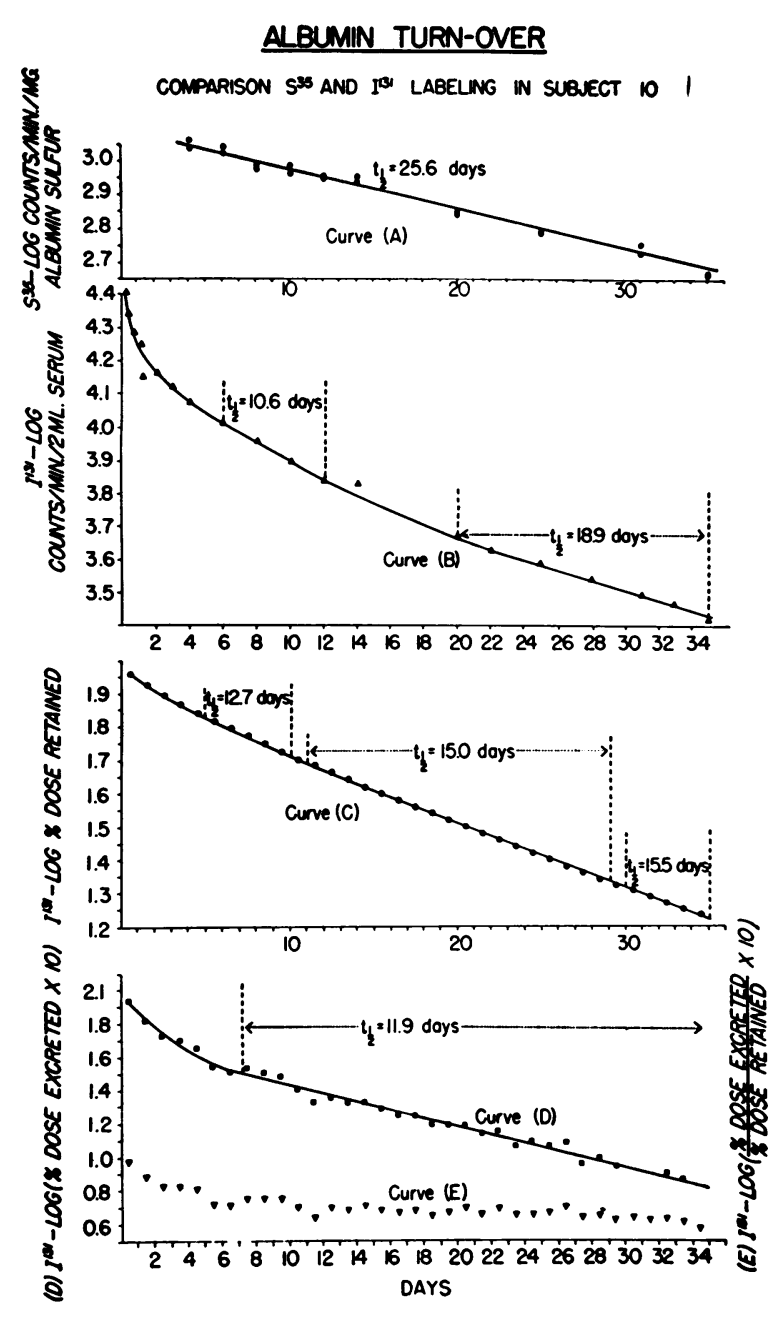

Figure 7

pools. Metabolic degradations of course occur simultaneously throughout this period, which has been analyzed by Forker and Chaikoff (32), Schoenberger, Kroll, Sakamoto, and Kark (33) and Berson, Yalow, Schreiber, and Post (34). Phase II varied in duration from one to eight days, in most cases being of two to four days' length. Phase III-Metabolic degradation of labeled plasma proteins. Differences between protein fractions in curve shape appeared in Phase III. For albumin, a steady exponential decline of specific activity was found in all subjects for the total duration of observation in Phase III (Curve B, Figure 3, Curve A in Figure 7). In contrast, for both beta-1 lipoprotein and fibrinogen, a semi-log plot of data in Phase III seemed to assume the shape of an exponential binomial curve
(Curve A, Figure 3; Curve 1, Figure 4), which could be resolved arbitrarily into two exponential components by graphic analysis (Curves 3 and 4, Figure 4). However, in all observations on fibrinogen and beta-1 lipoprotein fractions a straight line could reasonably be drawn through experimental points obtained during the period 4 to 11 days after isotope administration; thereafter, specific activity more slowly declined. The plotted data for Phase III of the Cohn Fraction I + III exhibited a steady exponential loss of isotope in all cases studied; the duration of these observations was, however, much more limited (Table VII). A semi-log plot of the total serum protein specific activity for Phase III usually appeared as a straight line, in spite of the fact that the curve reflected the varied metabolism of multiple protein components; in many instances there appeared to be a greater delay (up to 8 to 12 days) in reaching a constant slope than occurred with albumin ( 1 to 4 days).

With few exceptions, the data plotted for gamma globulins after oral administration of $\mathrm{S}^{35}$ labeled cystine exhibited a marked delay (often 10 to 14 days) before appreciable decrease of specific activity began. Thereafter, a steady exponential loss of isotope occurred. Thus, in this group of subjects, when the duration of observations was less than 14 days, little apparent turnover was observed (Table VIII). This was evident in spite of the fact that this fraction appeared maximally labeled within 24 hours of isotope administration. In contrast, subjects receiving donor-labeled plasma exhibited no unusual delay before showing a uniform decline of isotope in this component. The characteristic isotope die-away curves for the various plasma protein fractions are illustrated in Figure 5 by representative data plots obtained in a single subject for each method of $\mathrm{S}^{35}$ administration.

\section{Urinary $S^{35}$ excretion}

Urinary excretion of radioactive sulfur was followed for 40 days in three subjects $(7,8$, and 17$)$ receiving oral $\mathrm{S}^{35}$-labeled 1 -cystine, according to the general plan of Berson, Yalow, Schreiber, and Post (34). In a typical set of data, relating per cent of isotope dose excreted to per cent of administered isotope retained (Figure 2), a uniform 
TABLE III

Characterization beta-1 lipoprotein fraction

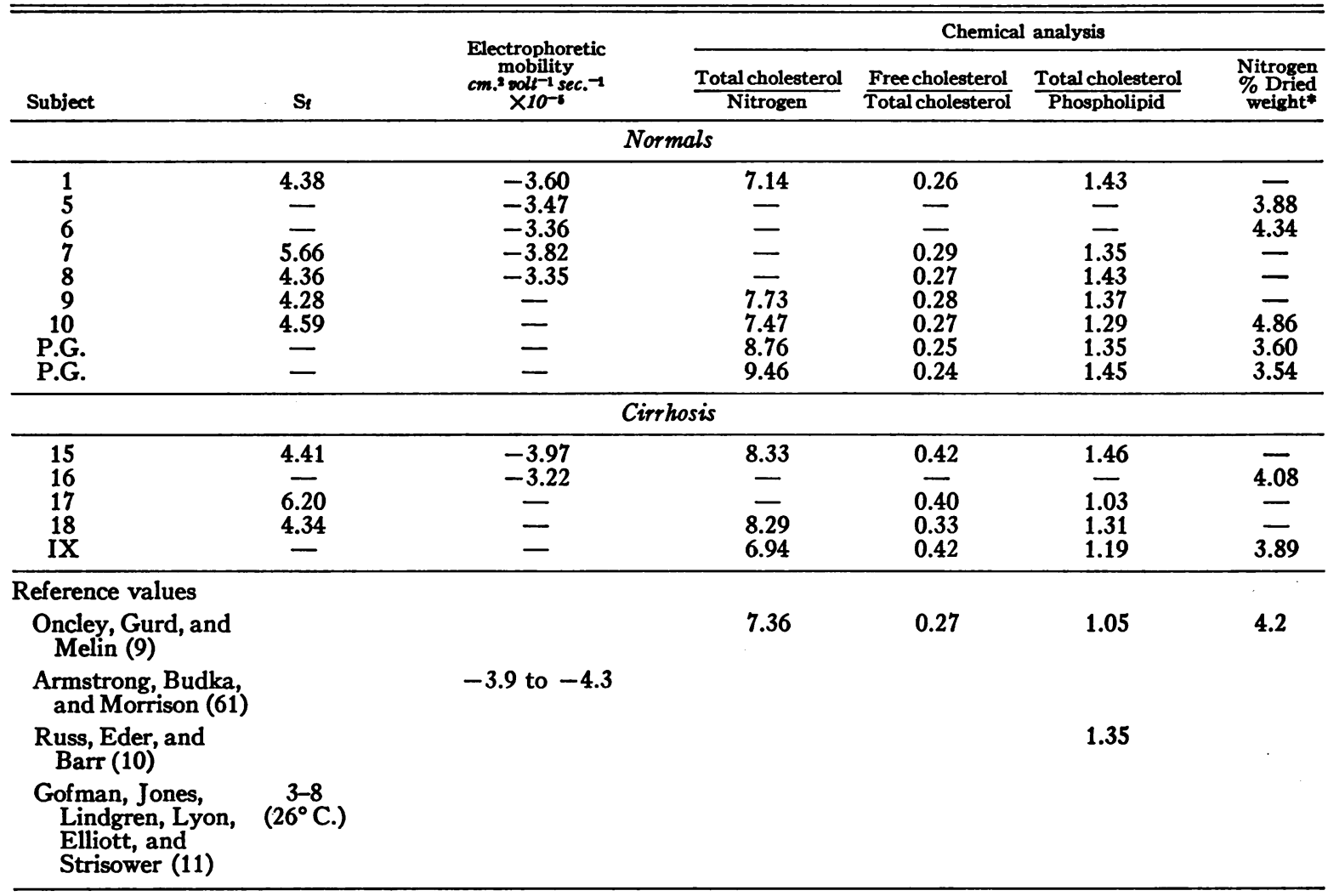

* Obtained by the directions of Oncley, Gurd, and Melin (9).

TABLE IV

Albumin turn-over *

\begin{tabular}{|c|c|c|c|c|c|c|c|c|c|}
\hline \multirow[b]{2}{*}{$\begin{array}{l}\text { Method } \\
\text { S }^{a x} \\
\text { adminis- } \\
\text { tration }\end{array}$} & \multirow[b]{2}{*}{ Subject } & \multirow[b]{2}{*}{$\begin{array}{c}\text { Weight } \\
K_{\mathbf{g} .}\end{array}$} & \multirow[b]{2}{*}{$\begin{array}{l}\text { Plasma } \\
\text { volume } \\
\text { ml. }\end{array}$} & \multirow[b]{2}{*}{$\begin{array}{l}\text { Albumin } \\
\text { conc. } \\
\text { gm./100 ml. } \\
\text { serum }\end{array}$} & \multirow[b]{2}{*}{$\begin{array}{c}\text { Total } \\
\text { plasma } \\
\text { albumin } \\
\text { gm. }\end{array}$} & \multirow[b]{2}{*}{$\begin{array}{l}\text { Plasma } \\
\text { albumin } \\
g m . / K_{g} . \\
\text { body wot. }\end{array}$} & \multicolumn{2}{|c|}{ Apparent half-life } & \multirow[b]{2}{*}{$\begin{array}{c}\text { Total } \\
\text { duration } \\
\text { observa- } \\
\text { tions } \\
\text { days }\end{array}$} \\
\hline & & & & & & & $\underset{t_{1}}{S_{\text {days }}}$ & $\begin{array}{c}\text { Im1 } \\
\text { slowest } \\
\text { compo- } \\
\text { nent } \\
t_{\text {t days }}\end{array}$ & \\
\hline \multicolumn{10}{|c|}{ Normal subjects } \\
\hline $\begin{array}{l}\text { Oral } \\
\text { Sw } \\
\text { Cystine }\end{array}$ & $\begin{array}{l}1 \\
2 \\
3 \\
5 \\
7 \\
8 \\
9\end{array}$ & $\begin{array}{l}68 \\
84 \\
77.3 \\
70 \\
70.5 \\
74.1 \\
86\end{array}$ & $\begin{array}{l}4,120 \\
2,632 \\
3,068 \\
2,667 \\
3,922 \\
3,489 \\
4,762\end{array}$ & $\begin{array}{l}4.05^{\circ} \\
3.95^{\circ} \\
4.46^{\circ} \\
4.18^{\circ} \\
4.54^{\circ} \\
4.15^{\circ} \\
4.38^{\circ}\end{array}$ & $\begin{array}{l}166.9 \\
104.0 \\
136.8 \\
111.5 \\
178.1 \\
144.8 \\
208.6\end{array}$ & $\begin{array}{l}2.45 \\
1.24 \\
1.77 \\
1.59 \\
2.52 \\
1.95 \\
2.42\end{array}$ & $\begin{array}{l}25.8 \\
44.3 \\
23.4 \\
26.7 \\
27.4 \\
27.4 \\
38.8\end{array}$ & 15.6 & $\begin{array}{r}9 \\
11 \\
15 \\
30 \\
39 \\
39 \\
36\end{array}$ \\
\hline $\begin{array}{l}\text { IV } \\
\text { Sas } \\
\text { Plasma }\end{array}$ & $\begin{array}{r}4 \\
6 \\
10\end{array}$ & $\begin{array}{c}73.6 \\
61.4 \\
100\end{array}$ & $\begin{array}{l}3,388 \\
3,041 \\
4,808\end{array}$ & $\begin{array}{l}4.16^{\circ} \\
4.54^{\circ} \\
4.75^{\circ}\end{array}$ & $\begin{array}{l}140.9 \\
138.1 \\
228.4\end{array}$ & $\begin{array}{l}1.91 \\
2.65 \\
2.28\end{array}$ & $\begin{array}{l}16.6 \\
22.3 \\
25.6\end{array}$ & 18.9 & $\begin{array}{l}14 \\
29 \\
35\end{array}$ \\
\hline \multicolumn{10}{|c|}{ Cirrhosis } \\
\hline $\begin{array}{l}\text { Oral } \\
\text { Sw }^{*} \\
\text { Cystine }\end{array}$ & $\begin{array}{l}11 \\
12 \\
17\end{array}$ & $\begin{array}{l}58 \\
52 \\
91.5\end{array}$ & $\begin{array}{l}3,589 \\
4,356 \\
3,840\end{array}$ & $\begin{array}{l}3.49^{\circ} \\
2.64^{\circ} \\
3.20^{\circ}\end{array}$ & $\begin{array}{l}125.3 \\
115.0 \\
122.9\end{array}$ & $\begin{array}{l}2.16 \\
2.21 \\
1.34\end{array}$ & $\begin{array}{l}25.4 \\
21.8 \\
62.6\end{array}$ & & $\begin{array}{l}11 \\
10 \\
39\end{array}$ \\
\hline $\begin{array}{l}\text { IV } \\
\text { Sæ } \\
\text { Plasma }\end{array}$ & $\begin{array}{l}15 \\
16 \\
18\end{array}$ & $\begin{array}{l}80 \\
58.5 \\
61.5\end{array}$ & $\begin{array}{l}5,910 \\
4,124 \\
4,098\end{array}$ & $\begin{array}{l}2.83^{\circ} \\
2.88^{\circ} \\
2.89^{\circ}\end{array}$ & $\begin{array}{l}167.3 \\
118.8 \\
118.4\end{array}$ & $\begin{array}{l}2.09 \\
2.03 \\
1.92\end{array}$ & $\begin{array}{l}24.5 \\
23.0 \\
26.1\end{array}$ & 24.9 & $\begin{array}{l}14 \\
29 \\
35\end{array}$ \\
\hline
\end{tabular}

$* \mathrm{e}=$ free electrophoretic determination $; \mathrm{c}=$ chemical determination. 
TABLE V

Fibrinogen turn-over

\begin{tabular}{|c|c|c|c|c|c|c|c|}
\hline \multirow{3}{*}{$\begin{array}{l}\text { Method } \\
\text { isotope } \\
\text { adminis- } \\
\text { tration }\end{array}$} & \multirow[b]{3}{*}{ Subject } & \multirow{3}{*}{$\begin{array}{c}\text { Fibrinogen } \\
\text { conc. } \\
\text { mg./100 ml. } \\
\text { plasma }\end{array}$} & \multicolumn{2}{|c|}{$\begin{array}{l}\text { Apparent half-life, } \\
\text { Graphic analysis No. 1* }\end{array}$} & \multirow{2}{*}{\multicolumn{2}{|c|}{$\begin{array}{c}\text { Determined } t_{3} \text { components, } \\
\text { Graphic analysis No. } 2 \dagger\end{array}$}} & \multirow{3}{*}{$\begin{array}{c}\text { Total } \\
\text { duration } \\
\text { observa- } \\
\text { tions } \\
\text { days }\end{array}$} \\
\hline & & & \multirow[b]{2}{*}{ t/ days } & \multirow{2}{*}{$\begin{array}{c}\text { Period } t_{\text {l }} \\
\text { calc. days } \\
\text { after intake } \\
\text { isotope }\end{array}$} & & & \\
\hline & & & & & $\begin{array}{c}\text { Fast } t_{3} \\
\text { days }\end{array}$ & $\underset{\text { days }}{\text { Slow }} t_{t}$ & \\
\hline \multicolumn{8}{|c|}{ Normal subjects } \\
\hline $\begin{array}{l}\text { Oral } \\
\text { S }^{25} \\
\text { Cystine }\end{array}$ & $\begin{array}{l}3 \\
5 \\
7 \\
8 \\
9\end{array}$ & $\begin{array}{l}- \\
293 \\
279 \\
286 \\
269\end{array}$ & $\begin{array}{l}5.6 \\
5.9 \\
6.7 \\
8.0 \\
7.1\end{array}$ & $\begin{array}{l}5-12 \\
5-12 \\
4-14 \\
4-17 \\
4-14\end{array}$ & $\begin{array}{l}1.7 \\
3.5 \\
4.7 \\
5.0 \\
4.5\end{array}$ & $\begin{array}{l}10.0 \\
20.7 \\
24.3 \\
31.4 \\
25.8\end{array}$ & $\begin{array}{l}15 \\
30 \\
39 \\
39 \\
36\end{array}$ \\
\hline $\begin{array}{l}\text { IV } \\
\text { S' } \\
\text { Plasma }\end{array}$ & $\begin{array}{r}4 \\
6 \\
10\end{array}$ & $\begin{array}{l}-\overline{251} \\
276\end{array}$ & $\begin{array}{l}4.2 \\
3.4 \\
3.7\end{array}$ & $\begin{array}{l}4-14 \\
4-11 \\
4-12\end{array}$ & $\begin{array}{l}\overline{2.7} \\
2.1\end{array}$ & $\begin{array}{l}\overline{18.0} \\
10.6\end{array}$ & $\begin{array}{l}14 \\
29 \\
31\end{array}$ \\
\hline \multicolumn{8}{|c|}{ Cirrhosis } \\
\hline Oral & 14 & - & 10.7 & $2-14$ & - & - & 14 \\
\hline Cystine & 17 & 245 & 10.9 & 4-17 & 6.2 & 26.0 & 39 \\
\hline $\begin{array}{l}\text { IV } \\
\text { Ss } \\
\text { Plasma }\end{array}$ & $\begin{array}{l}15 \\
16 \\
18\end{array}$ & $\begin{array}{l}\overline{251} \\
357\end{array}$ & $\begin{array}{l}4.7 \\
4.0 \\
5.2\end{array}$ & $\begin{array}{l}4-14 \\
4-11 \\
5-15\end{array}$ & $\begin{array}{l}\overline{2.8} \\
3.3\end{array}$ & $\begin{array}{l}\overline{31.7} \\
24.8\end{array}$ & $\begin{array}{l}14 \\
29 \\
35\end{array}$ \\
\hline
\end{tabular}

* As per Curve 2 of Figure 4.

† As per Curves 3 and 4 of Figure 4 ; approximately 80 to 85 per cent contribution by fast component when extrapolated to zero time.

TABLE VI

$\beta_{1}$ lipoprotein turn-over

\begin{tabular}{|c|c|c|c|c|c|c|c|}
\hline \multirow{3}{*}{$\begin{array}{l}\text { Method } \\
\text { isotope } \\
\text { adminis- } \\
\text { tration }\end{array}$} & \multirow[b]{3}{*}{ Subject } & \multirow{3}{*}{$\begin{array}{c}\beta_{1} \text { lipo- } \\
\text { protein } \\
\text { conc. } \\
\text { mg./100 ml. } \\
\text { serum }\end{array}$} & \multicolumn{2}{|c|}{$\begin{array}{l}\text { Apparent half-life, } \\
\text { Graphic analysis No. 1* }\end{array}$} & \multirow{2}{*}{\multicolumn{2}{|c|}{$\begin{array}{l}\text { Determined } t_{3} \text { components, } \\
\text { Graphic analysis No. } 2 \dagger\end{array}$}} & \multirow{3}{*}{$\begin{array}{c}\text { Total } \\
\text { duration } \\
\text { observa- } \\
\text { tions } \\
\text { deys }\end{array}$} \\
\hline & & & \multirow[b]{2}{*}{ ti days } & \multirow{2}{*}{$\begin{array}{c}\text { Period } t_{\xi} \\
\text { calc. days } \\
\text { after intake } \\
\text { isotope }\end{array}$} & & & \\
\hline & & & & & $\begin{array}{c}\text { Fast } t_{3} \\
\text { days }\end{array}$ & $\begin{array}{c}\text { Slow } t_{t} \\
\text { days }\end{array}$ & \\
\hline \multicolumn{8}{|c|}{ Normal subjects } \\
\hline $\begin{array}{l}\text { Oral } \\
\text { Sw }^{*} \\
\text { Cystine }\end{array}$ & $\begin{array}{l}3 \\
5 \\
7 \\
8 \\
9\end{array}$ & $\begin{array}{c}\overline{330} \\
250 \\
300 \\
-\end{array}$ & $\begin{array}{l}3.1 \\
4.8 \\
7.4 \\
6.3 \\
6.1\end{array}$ & $\begin{array}{l}3-8 \\
5-12 \\
4-17 \\
4-14 \\
5-11\end{array}$ & $\begin{array}{r}11.4 \\
2.5 \\
4.5 \\
4.2 \\
3.5\end{array}$ & $\begin{array}{l}10.8 \\
12.2 \\
63.1 \\
16.5 \\
13.7\end{array}$ & $\begin{array}{l}15 \\
30 \\
39 \\
39 \\
36\end{array}$ \\
\hline $\begin{array}{l}\text { IV } \\
\text { Ses } \\
\text { Plasma }\end{array}$ & $\begin{array}{r}4 \\
6 \\
10\end{array}$ & $\begin{array}{l}\overline{170} \\
150\end{array}$ & $\begin{array}{l}3.8 \\
3.0 \\
2.9\end{array}$ & $\begin{array}{l}4-14 \\
4-16 \\
4-10\end{array}$ & $\begin{array}{l}1.6 \\
2.1 \\
1.0\end{array}$ & $\begin{array}{r}6.5 \\
10.0 \\
7.3\end{array}$ & $\begin{array}{l}14 \\
29 \\
35\end{array}$ \\
\hline \multicolumn{8}{|c|}{ Cirrhosis } \\
\hline $\begin{array}{l}\text { Oral } \\
\text { S }^{\star 2} \\
\text { Cystine }\end{array}$ & 17 & 280 & 10.0 & $6-14$ & 4.2 & 21.0 & 39 \\
\hline $\begin{array}{l}\text { IV } \\
\text { S*6 } \\
\text { Plasma }\end{array}$ & $\begin{array}{l}15 \\
16 \\
18\end{array}$ & $\overline{220}$ & $\begin{array}{l}6.1 \\
3.4 \\
5.0\end{array}$ & $\begin{array}{l}2-11 \\
5-11 \\
4-12\end{array}$ & $\begin{array}{l}\overline{2.2} \\
1.6\end{array}$ & $\begin{array}{r}\overline{15.5} \\
9.8\end{array}$ & $\begin{array}{l}11 \\
29 \\
35\end{array}$ \\
\hline
\end{tabular}

* As per Curve 2 of Figure 4.

$\dagger$ As per Curves 3 and 4 of Figure 4 ; approximately 80 to 85 per cent contribution by fast component when extrapolated to zero time. 
TABLE VII

Turn-over Cohn $I+I I I$ fraction *

\begin{tabular}{|c|c|c|c|}
\hline \multicolumn{4}{|c|}{ Oral Sa cystine } \\
\hline Subject & $t_{1}$ days & $\begin{array}{l}\text { Period t } \\
\text { calc. days } \\
\text { following } \\
\text { intake } \\
\text { isotope }\end{array}$ & $\begin{array}{c}\text { Total } \\
\text { duration } \\
\text { observa- } \\
\text { tions } \\
\text { days }\end{array}$ \\
\hline \multicolumn{4}{|c|}{ Normal subjects } \\
\hline $\begin{array}{l}1 \\
2\end{array}$ & $\begin{array}{l}6.2 \\
7.8\end{array}$ & $\begin{array}{l}2-9 \\
2-11\end{array}$ & $\begin{array}{r}9 \\
11\end{array}$ \\
\hline \multicolumn{4}{|c|}{ Cirrhosis } \\
\hline $\begin{array}{l}11 \\
12 \\
13\end{array}$ & $\begin{array}{r}11.1 \\
8.9 \\
10.4\end{array}$ & $\begin{array}{c}3-11 \\
2-9 \\
1.5-11\end{array}$ & $\begin{array}{r}11 \\
9 \\
11\end{array}$ \\
\hline
\end{tabular}

* About 60 per cent of this fraction is $\beta_{1}$ lipoprotein.

daily per cent excretion of isotope was not observed. This would seem expected inasmuch as urinary excretion of isotope should reflect the widely differing rates of catabolism of many varieties of body proteins labeled by $S^{35}$ cystine, as well as reutilization of isotope among all compounds of the body's organic sulfur pool. Since the amount of isotope administered by the infusion of labeled plasma was small, it did not seem possible to study accurately $\mathrm{S}^{35}$ excretion over a similarly prolonged period in these cases.

TABLE VIII

\begin{tabular}{|c|c|c|c|c|}
\hline \multicolumn{5}{|c|}{ Turn-over gamma globulins * } \\
\hline $\begin{array}{l}\text { Method } \\
\text { isotope } \\
\text { adminis- } \\
\text { tration }\end{array}$ & Subject & $\begin{array}{c}\text { Apparent } \\
\text { half-life } \\
\mathbf{t} \text { days }\end{array}$ & $\begin{array}{c}\text { Total } \\
\text { duration } \\
\text { observa- } \\
\text { tions } \\
\text { days }\end{array}$ & $\begin{array}{c}\text { Concen- } \\
\text { tration } \\
\boldsymbol{\gamma} \text { globulins } \\
\boldsymbol{g m} . / 100 \\
\text { ml. serum }\end{array}$ \\
\hline \multicolumn{5}{|c|}{ Normal subjects } \\
\hline $\begin{array}{l}\text { Oral } \\
\text { Sas }^{a s} \\
\text { Cystine }\end{array}$ & $\begin{array}{l}1 \\
2 \\
7 \\
8 \\
9\end{array}$ & $\begin{array}{l}\infty \\
71 \\
48 \\
49 \\
85\end{array}$ & $\begin{array}{r}9 \\
11 \\
39 \\
39 \\
36\end{array}$ & $\begin{array}{l}1.1^{\circ} \\
1.2^{\circ} \\
0.80^{\circ} \\
0.87^{\circ} \\
0.73^{\circ}\end{array}$ \\
\hline $\begin{array}{l}\text { IV } \\
\text { S's } \\
\text { Plasma }\end{array}$ & $\begin{array}{r}4 \\
6 \\
10\end{array}$ & $\begin{array}{l}19.7 \\
25 \\
35 \\
\end{array}$ & $\begin{array}{l}14 \\
29 \\
35\end{array}$ & $\begin{array}{l}0.67^{\circ} \\
0.94^{\circ} \\
0.80^{\circ}\end{array}$ \\
\hline \multicolumn{5}{|c|}{ Cirrhosis } \\
\hline $\begin{array}{l}\text { Oral } \\
\text { S's } \\
\text { Cystine }\end{array}$ & $\begin{array}{l}11 \\
12 \\
13 \\
14 \\
17\end{array}$ & $\begin{array}{r}150 \\
130 \\
51 \\
151 \\
31\end{array}$ & $\begin{array}{r}9 \\
9 \\
11 \\
14 \\
39\end{array}$ & $\begin{array}{l}1.2^{\circ} \\
2.1^{\circ} \\
1.9^{\circ} \\
1.99^{\circ} \\
3.10^{\circ}\end{array}$ \\
\hline $\begin{array}{l}\text { IV } \\
\text { Ses }\end{array}$ & 16 & 40 & 29 & $2.70^{\circ}$ \\
\hline Plasma & 18 & 51 & 35 & $2.47^{\circ}$ \\
\hline
\end{tabular}

* $c=$ chemical determination (36); $e=$ free electrophoretic determination.
Turn-over data, various protein fractions

From the summary of turn-over data for albumin in Tables IV and X, it appears that the apparent turn-over time is slightly shorter for normal subjects infused with $S^{35}$-labeled plasma than for those fed $\mathrm{S}^{35}$-labeled cystine. No clear differences between the $S^{85}$ data for normal subjects and patients with cirrhosis are observed.

The turn-over curves for $I^{131}$-labeled albumin indicated the presence of components of varying half-times, similar to the observations of Berson,

TABLE IX

Turn-over serum total proteins

\begin{tabular}{|c|c|c|c|c|c|}
\hline $\begin{array}{l}\text { Method } \\
\text { isotope } \\
\text { adminis- } \\
\text { tration }\end{array}$ & Subject & $\begin{array}{c}\text { Total } \\
\text { protein } \\
\text { conc. } \\
\text { gm./100 } \\
\text { ml. serum }\end{array}$ & $\begin{array}{c}\text { Apparent } \\
\text { half-life } \\
\text { days }\end{array}$ & $\begin{array}{c}\text { Period } t_{\text {f }} \\
\text { calc. days } \\
\text { following } \\
\text { intake } \\
\text { isotope }\end{array}$ & $\begin{array}{c}\text { Total } \\
\text { duration } \\
\text { obeerva- } \\
\text { tions } \\
\text { days }\end{array}$ \\
\hline \multicolumn{6}{|c|}{ Normal subjects } \\
\hline $\begin{array}{l}\text { Oral } \\
\text { Sas } \\
\text { Cystine }\end{array}$ & $\begin{array}{l}1 \\
2 \\
3 \\
7 \\
8 \\
9\end{array}$ & $\begin{array}{l}7.48 \\
7.57 \\
7.15 \\
7.39 \\
7.91 \\
6.91\end{array}$ & $\begin{array}{l}14.4 \\
30.1 \\
20.4 \\
23.5 \\
23.8 \\
38.8\end{array}$ & $\begin{array}{l}1-9 \\
3-11 \\
5-15 \\
8-31 \\
4-39 \\
4-36\end{array}$ & $\begin{array}{r}9 \\
11 \\
15 \\
39 \\
39 \\
36\end{array}$ \\
\hline $\begin{array}{l}\text { IV } \\
\text { S }^{25}\end{array}$ & 4 & 7.27 & 12.7 & 4-14 & 14 \\
\hline Plasma & 10 & 7.52 & 23.5 & $8-35$ & 35 \\
\hline \multicolumn{6}{|c|}{ Cirrhosis } \\
\hline $\begin{array}{l}\text { Oral } \\
\text { S5 } \\
\text { Cystine }\end{array}$ & $\begin{array}{l}11 \\
12 \\
13 \\
14 \\
17\end{array}$ & $\begin{array}{l}7.29 \\
8.00 \\
6.25 \\
6.98 \\
8.30\end{array}$ & $\begin{array}{l}20.0 \\
17.7 \\
24.4 \\
26.8 \\
36.3\end{array}$ & $\begin{array}{c}3-11 \\
1-9 \\
1.5-11 \\
2-9 \\
4-39\end{array}$ & $\begin{array}{r}11 \\
9 \\
11 \\
9 \\
39\end{array}$ \\
\hline $\begin{array}{l}\text { IV } \\
\text { S }^{85}\end{array}$ & 15 & 7.54 & 30.8 & $7-14$ & 14 \\
\hline Plasma & 18 & 7.80 & 30.0 & $12-35$ & 35 \\
\hline
\end{tabular}

Yalow, Schreiber, and Post (34). In each subject, the slowest component observed after 8 to 14 days, yielded a half-life value of the same range as reported by Berson, Yalow, Schreiber, and Post for "satisfactorily" iodinated albumins. Early high urinary excretion of $\mathrm{I}^{131}$ reflected the presence of rapidly degraded components in the injected albumin preparation (Table II).

In fibrinogen and beta-1 lipoprotein fractions, as with albumin, there appeared to be a somewhat longer apparent half-life in subjects fed labeled amino acid precursor as compared with values obtained following injection of $S^{35}$-labeled plasma (Tables V and VI). The data suggest a slightly 
TABLE $\mathbf{X}$

Published biosynthetic turn-over data, human plasma proteins

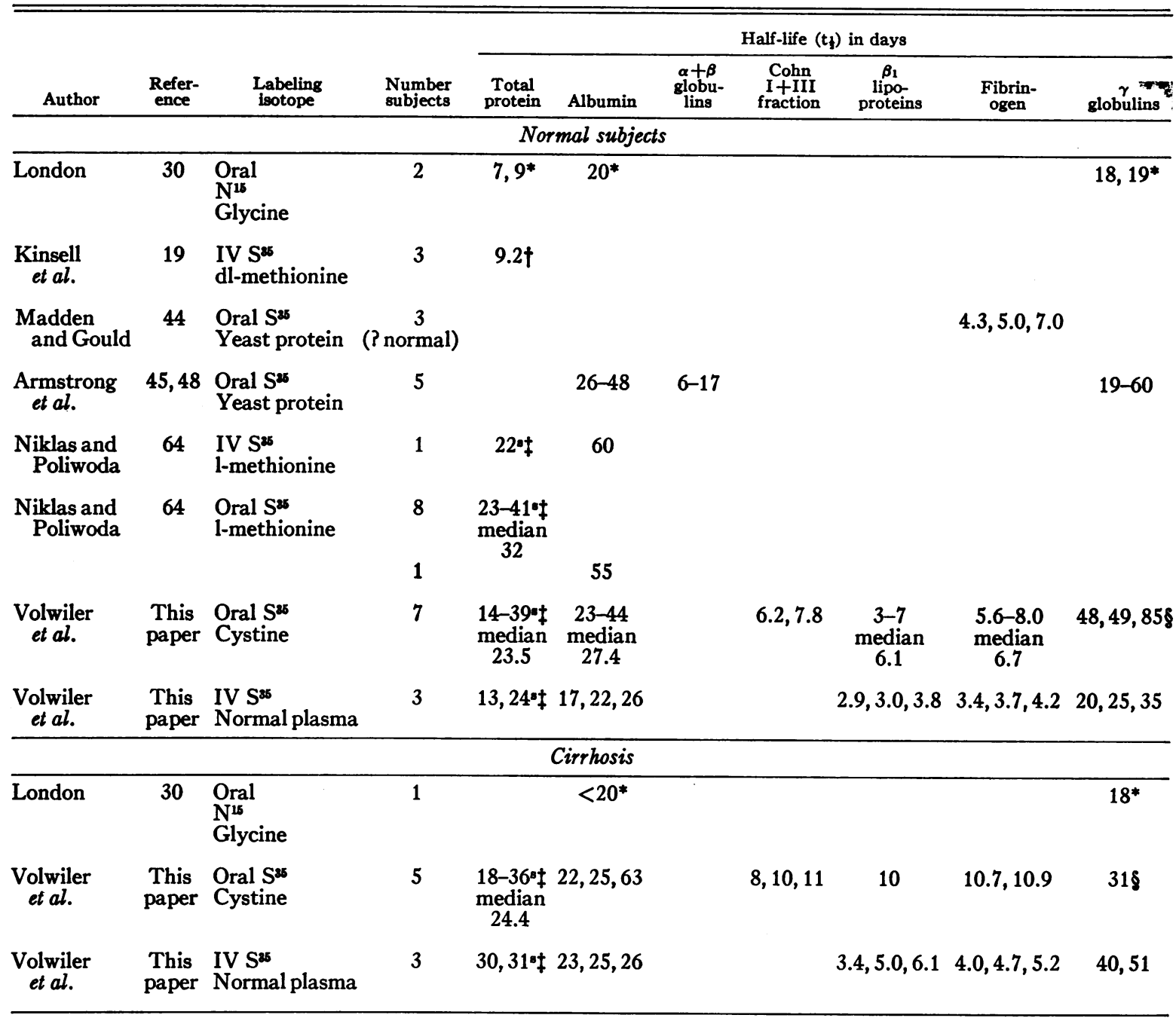

* Longer if only points after completion of mixing phase are considered.

† This figure was obtained by Tarver (31) by replotting the original data. Our replot of Kinsell's published data indicates a much longer half-time if only points after four days following isotope administration are considered (that is, after completion of mixing phase).

$\ddagger \mathrm{s}=$ serum.

Subjects followed longer than 20 days.

longer turn-over time for beta-1 lipoproteins in cirrhosis as compared with the normal state.

Half-lives obtained for serum total protein were considerably longer than reported for plasma total protein by others (Tables IX and X). The elimination through clotting of the rapidly turningover fibrinogen component does not explain fully this discrepancy. The chief explanation is that these early reports included the usual two- to four-day mixing period in the calculation of halflife. The vast heterogeneity of molecular species and multiple differences between normal and abnormal subjects in specific plasma proteins does not invite comparison between normal and cirrhotic subjects for this determination.

The isolated gamma globulin fractions were composed of a continuous spectrum of gamma globulins (35). The same protein species were perhaps not present in our normal and cirrhotic subjects, and increases of total gamma globulin in the various cirrhotic patients could have represented different qualitative as well as quantitative 
changes in these species. Therefore, as with total serum proteins, there is very limited value in comparing the half-life values between normal and cirrhotic subjects. For reasons mentioned, only gamma globulin values obtained following transfusion of donor-labeled plasma are considered significant (Table VIII).

\section{DISCUSSION}

\section{The organic sulfur pool}

Radioactive sulfur introduced in the form of l-cystine or tagged plasma protein containing $\mathrm{S}^{35}$ labeled cystine may be expected to follow a distribution in the body's organic sulfur pool according to the pathways shown in Figure 6. This diagram points out the possible advantage of labeling less of the total pool by using tagged 1-cystine as compared to the total labeling which would result from introducing $S^{35}$ in 1-methionine.

\section{Basic general assumptions}

Three assumptions are made in interpreting these turn-over data: 1) All of the radioactive sulfur in the isolated protein fractions is tightly incorporated into the protein molecules as 1-cystine or 1-cysteine by peptide linkage. Evidence that circulating $\mathrm{S}^{35}$, within a few hours following its introduction into the body as cystine or methionine, exists firmly chemically-bound in plasma proteins has been previously furnished by both Tarver and Reinhardt (37) and Lee, Anderson, Miller, and Williams (38) ; mercaptoethanol treatment of the total serum proteins of one subject, according to the methods described by Lee, Anderson, Miller, and Williams (38) and by Peterson and Greenberg (39), did not disclose appreciable loose attachment of extra $S^{35}$-labeled cystine to circulating protein by disulfide linkage (Graph A, Figure 2). It has been generally assumed that all sulfur present in plasma protein molecules exists in the form of cystine, cysteine, or methionine residues attached by peptide bonds. However, other types of firm binding are possible: Studies in vitro by Schöberl (40) have shown that sulfur can be introduced into proteins by attachment of a sulfhydryl group onto the $\epsilon$-amino nitrogen of lysine through action of polythioglycolide; and recently, the presence of a firm sulfate radical in bovine fibrinogen has been identified by Bettelheim $(41)$; 2) The rate of disappearance of the sulfur label reflects the rate of disintegration of the whole plasma protein molecule. Certainly the manner in which plasma proteins are catabolized is at present unknown. Evidence indicating that, while circulating, certain plasma proteins do not exchange their amino acid residues has been presented by Humphrey and McFarlane $(42) ; 3$ ) The rates of synthesis and degradation are equal for a plasma protein. This seems probable since all subjects were in a relatively "steady state," both prior to and during the period of observations, with unchanging concentrations of serum proteins, regular daily activities, relatively constant high protein diet, and stationary state of the liver disease if present.

\section{Errors of half-life determination}

It is difficult to explain adequately the wide variation in apparent half-lives within specific fractions as obtained with $\mathrm{S}^{35}$. Aside from normal expectation of biologic variation, errors and limitations of the laboratory techniques must be scrutinized. Random errors of this type could result in the scattering of small groups of plotted points so as to falsely orient the isotope die-away curve. The likely magnitude of this error was found small, there being little possible variation in choice as to slope of the isotope curve. An additional unassessed influence is the variation between individual subjects in the homogeneity of any specific plasma protein fraction isolated. Even relatively small amounts of protein contaminant having a markedly different half-life could significantly alter the values for the major component. Differences in physical and chemical properties, and concentrations of the various plasma protein components in both normal and abnormal sera might be expected to influence the reproducibility of the fractionation procedures employed. In a single subject, ultracentrifugal and electrophoretic analyses of a fraction isolated at different intervals following isotope administration showed reproducible though not always absolute homogeneity. However, even if a fraction were homogeneous by these criteria there is still the possibility of different molecular species being present in the protein.

Following oral administration of $\mathrm{S}^{35}$-labeled 
cystine, an error of unknown degree in prolonging the apparent half-life of plasma proteins may result from reutilization of isotope contributed to the body's organic sulfur pool by the catabolism of these and other labeled body proteins. The experiments in transfusing normal donor-labeled $\mathrm{S}^{36}$. labeled plasma were carried out to appraise this problem. Even here, some reutilization by the more slowly turning-over fractions of the isotope contributed by the rapidly catabolized plasma proteins seems possible. This would seem particularly likely if the principal cellular site of destruction of the more rapid turning-over components were identical with the site of synthesis of other fractions. Slightly shorter half-times for fractions studied after plasma transfusion as compared with half-times of corresponding fractions measured after administering cystine suggests that isotope reutilization may produce error in prolonging the apparent rate of loss of isotope; a further accumulation of data has therefore reversed our previous opinion of this problem (43). Variation between subjects in degrees of isotope reutilization could account for differences in various half-lives. None of our subjects received during study supplements of non-labeled sulfur amino acids beyond these amounts contained in the usual high-protein diet. Though, logically, a further such flooding of the organic sulfur pool with non-labeled compounds should cause appreciable dilution of the labeled amino acids and thereby limit reutilization of isotope during synthesis of plasma proteins, conclusive data on this point have not yet been published. Indeed, the small amount of negative data from experiments in which supplementary nonlabeled 1-methionine or 1-cystine was administered (presented by Madden and Gould [44], by Armstrong, McLeod, Wolter, and Kukral [45], and obtained in two pilot experiments on dogs by us) raises considerable doubt as to whether such influence would be of any real importance in these determinations.

\section{Comparison of $S^{35}$ with $I^{131}$ labeling}

Using $S^{35}$ labeling, the turn-over time obtained for albumin by either of the two biosynthetic methods was much longer in two of the three subjects compared than determined by injecting $\mathrm{I}^{131}$ labeled albumin ${ }^{23}$ (Table IV). Our half-times for iodinated albumin lie within the lower portion of the range found by Berson, Yalow, Schreiber, and Post (34) employing iodinating albumin techniques considered most satisfactory. In our experiments also, urinary $\mathrm{I}^{131}$ excretion rates agreed in general with plasma $I^{131}$ disappearance, and reflected a changing exponential rate of $\mathrm{I}^{181}$ discard (Figure 7). As noted by Berson, Yalow, Schreiber, and Post, the isotope disappearance curves of our $\mathrm{I}^{131}$-labeled albumin also showed in each subject the presence of components rapidly losing the iodine label. The plotted data for plasma eventually assumed a steady exponential rate of isotope loss; ${ }^{24}$ this slowest component has been selected as the half-time for iodinated albumin herein reported (Table IV). Even greater differences have been noted between the half-times of $\mathrm{S}^{35}$ and $\mathrm{I}^{131}$-labeled gamma globulins; the $\mathrm{S}^{35}$ turn-over values observed in our laboratory and those obtained by Armstrong and co-workers (45, 48) are considerably longer than reported (48-53) for I ${ }^{131}$-labeled human gamma globulin. Three explanations for this discrepancy in exponential rates are possible: (a) Proteins may be partially denatured by the iodinating techniques employed; (b) Introduction of the iodine atom may alter physical and biologic properties of native protein; and (c) Reutilization of $S^{35}$ following biosynthetic labeling causes lengthening of apparent turn-over time.

Considerable evidence has accumulated to indicate that in vitro iodination of proteins may have a variable effect upon physical characteristics and biologic properties with considerable shortening of life-span: Berson, Yalow, Schreiber, and Post (34) have shown that turn-over times for iodinated human albumin may vary according to the

\footnotetext{
23 Margen and Tarver $(46,47)$ have also noted in the same normal subject shorter turn-over times for $\mathrm{I}^{\mathrm{mi}}$ labeled albumin than obtained for $\mathrm{S}^{25}$-labeled albumin; $\mathrm{S}^{25}$ turn-over was measured both after administration of $S^{25}$-labeled amino acids and following intravenous injection of donor-labeled $S^{25}$ albumin. Slowest components of the iodinated albumin preparations gave half-time values of 17 to 25 days, as compared with 24 to 30 days for intravenously administered $S^{25}$-labeled albumin and 36 to 60 + days for $S^{25}$-labeled albumin following intravenous administration of $\mathrm{S}^{26}$-labeled amino acids.

24 Following the eighth day for subject 9, but after the twentieth day in subjects 10 and 18.
} 
particular chemical iodinating technique employed. Berson's data and ours demonstrate the non-uniform rate of $I^{181}$ disappearance usually observed following the injection of iodinated albumin. Gabrieli, Goulian, Kinersly, and Collet (54) have demonstrated electrophoretic non-homogeneity of certain iodinated albumins. Iodination of growth hormone (55) or of insulin (56) may alter physiologic activity of these proteins; in addition, the possible influence of radiation denaturation from $I^{181}$ has been mentioned (57). Whether intravenous transfer of biosynthetically labeled plasma proteins will allow more accurate determination of biologic life span than will present-day in vitro chemical labeling techniques has not yet been determined.

\section{Interpretation of fibrinogen, beta-1 lipoprotein and gamma globulin turn-over curves}

The interpretation of the turn-over curves for $\beta_{1}$ lipoprotein and fibrinogen is particularly difficult and uncertain. At least four explanations for the changing rate of isotope discard must be considered: (a) Re-introduction of isotope label. Since these appear to be very rapidly turning-over proteins with respect to the $S^{35}$ label, reintroduction of discarded isotope could occur to a greater degree than found in the more slowly metabolized plasma proteins. The degree of reutilization might be much greater than in other fractions if a principal site of catabolism of these or other highlylabeled proteins were identical with the locus of synthesis of fibrinogen and beta-1 lipoprotein. (b) Non-homogeneity of protein fraction, containing components of differing turn-over rates. Presumably this beta-1 lipoprotein fraction is not a homogeneous molecular species $(11,58)$, while the fibrinogen fractions appraised were non-homogeneous electrophoretically and by clottability. (c) Localized variations in metabolic rates. Different metabolic sites may have different rates of synthesis and degradation of a specific protein or exchange varying quantities of cystine residues and at different positions in the protein molecule. In the rat, the data of Miller, Bale, and Bly (59, 60 ) indicate principal hepatic origin of plasma proteins other than gamma globulin. (d) Prolonged and inefficient mixing of labeled proteins among various body fluid compartments. Evi- dence from various sources is accumulating to indicate that the different plasma protein-containing fluid compartments of the body vary in their efficiency and speed of equilibration with circulating plasma. In addition, the possibility exists that different plasma proteins do not equilibrate among these fluid pools at the same rate.

Although these various influences cannot be individually assessed, the error from reintroduction of isotope appears important and increases proportionately with time; therefore, the slope of the straight-line early portion of Phase III (4 to 12-day period) of the curve of decline in specific activity has been chosen as the apparent half-time to be reported herein for each of these two fractions (Tables V and VI).

For the purposes of describing the general character of the isotope die-away curves for fibrinogen and beta-1 lipoprotein samples, these curves have been analyzed graphically and found to be resolvable into a 2-component exponential system (Figure 4). This type of mathematical analysis has become well established for describing certain varieties of biological systems as studied with isotopic tracers $(62,63)$. In the present experiments, the biochemical system is so complex that the meaning of such derived constants is unknown. Presumably each derived constant is actually composed of a family of varying exponential rates describing the various types of isotope transfer within the body's organic sulfur pool. Neither of these constants can be assumed to represent the exact turn-over rate of a protein. However, in the experiments in which transfused labeled plasma was administered, reutilization of isotope appears to have minimal influence upon the complexity of this system, and it is therefore suggested that the fast derived component may approach the true rate of discard of $S^{35}$ from the principal protein species. Also, in the plasma transfer experiments, the slow derived constant may reflect chiefly the rate of turn-over of a contaminating slower catabolizing protein.

In considering the isotope curves for gamma globulins of subjects receiving oral $\mathrm{S}^{88}$-labeled cystine, the strikingly long delay after maximal labeling before appreciable loss of specific activity occurred suggests strong influence of either selective reutilization of isotope or delay in distribution into plasma of newly-formed, highly-labeled 
gamma globulin components. Therefore, for this fraction, values obtained after transfusion of labeled plasma seem far more significant.

\section{Comparison of turn-over data between normal and cirrhotic subjects}

It is of particular interest to note that the total mass of circulating plasma albumin in the patients with cirrhosis having low albumin concentrations was within the range of values found for normal subjects (Table IV). Presumably this reflects dilution of circulating albumin by increase in plasma volume related, in part, to expansion of collateral portal venous circulation. Of greater accuracy in such comparison would have been actual determination of Total Exchangeable Albumin; in edema-free subjects (normals and cirrhotics), the total amount of extravascular albumin was found by Berson, Yalow, Schreiber, and Post (34) to be surprisingly constant among various individuals, and averaged 60 per cent of the body's total albumin mass.

Our results with $\mathrm{S}^{35}$ for albumin turn-over suggest that patients with advanced portal cirrhosis having low plasma albumin concentrations may have a normal rate of albumin synthesis and catabolism. In some, this is understandable inasmuch as the determined total circulating plasma albumin mass may actually lie within normal limits. In those subjects having smaller than normal albumin pools, it could be suggested that the damaged liver's albumin-synthesizing machinery was simply smaller and therefore its daily total production is less; to maintain constant size of the body's albumin pool, daily albumin catabolism would then also need to decrease proportionately.

The difficulty of determining if there are differences from the normal in life-span of various molecular species in advanced cirrhosis is increased by the apparent spread of half-time values of the various fractions in each group of subjects. Certainly, metabolically significant alterations of half-lives could exist in diseased states which would fall within such a wide spread of values for the normal, therefore remaining undetected. Only very gross discrepancies in biologic life span would be recognized under these conditions. The small number of biosyntheticallydetermined life spans of the various plasma pro- teins accumulated in normal subjects and in patients with cirrhosis (Table $\mathrm{X}$ ) does not permit final statements of clear comparison.

\section{SUM MARY}

1. An attempt has been made to measure turnover times in normal and cirrhotic human subjects for total serum proteins, albumin, $\beta_{1}$ lipoprotein, fibrinogen, and gamma globulins, using oral $\mathrm{S}^{35}$ cystine and infused $\mathrm{S}^{35}$-labeled normal plasma.

2. The plasma protein fractions analyzed were isolated by means of differential solubility, selective ion-binding, and ultracentrifugal flotation.

3. Accurate determination of exact rates of plasma protein synthesis and degradation have not been possible with these techniques. Mixing times, delays in return of protein or isotope to the circulating plasma, reutilization of isotope, and other numerous complexities of the biochemical system are such that the specific activity die-away curves obtained cannot be accepted as representing the true degradation rate of the protein fraction at any time in the experiments.

4. Transfused labeled plasma protein yielded shorter apparent turnover times than were obtained following oral administration of the labeled amino acid. This supports the conclusion that reutilization of isotope liberated from the catabolism of labeled body proteins does introduce an appreciable error of apparent lengthening of the $\mathrm{t} 1 / 2$ times. Since this error would seem minimal for those experiments in which intravenous transfer of donor-labeled plasma protein was accomplished, it is believed that the $t \frac{1}{2}$ values obtained by this means may approach the true turn-over rates of the various isolated plasma protein fractions.

5. Fibrinogen and $\beta_{1}$ lipoprotein appear to be very much more rapid in turn-over with respect to the sulfur label than do albumin, gamma globulins or total serum proteins. After transfusing labeled plasma, apparent half-life values in the normal subject for fibrinogen and $\beta_{1}$ lipoprotein averaged 3.5 days as compared with a median of 21.5 days for albumin and 25 days for gamma globulins.

6. Comparison in the same subject of "turnover" of chemically iodinated albumin with "turn- 
over" of biosynthetically sulfur-labeled albumin demonstrated a variety of populations of iodinated albumin molecules having differing rates of catabolism; this suggested partial denaturation of albumin by the iodinating method. Those albumin components slowest in rate of discard of $\mathrm{I}^{131}$ gave an apparent half-life slightly shorter than was obtained with $\mathrm{S}^{35}$ labeling.

7. Variation in apparent half-life rendered comparison difficult between normal and cirrhotic subjects. $\beta_{1}$ lipoproteins appeared to have a slightly longer biologic life-span in the cirrhotic, whereas no gross differences were noted for albumin, fibrinogen or total serum proteins. Data on gamma globulins were insufficient for comparison.

\section{ACKNOWLEDGMENT}

The authors wish to express their gratitude to Mrs. Dorothy Shook, Mrs. Gertrude Douglas, Miss Alys Harty, and Dr. Robert M. Hegstrom for additional technical assistance. The authors are indebted to many for advice and direct aid in establishing the various laboratory methods, particularly to Drs. Norman D. Lee, Laurance W. Kinsell, Sheldon Margen, and Harold Tarver in regard to $S^{*}$ and total sulfur techniques; and to Drs. Frank R. N. Gurd, William H. Batchelor, Henry G. Kunkel, and Miss Ella M. Russ with respect to methods of plasma protein fractionation. Appreciation is expressed to Dr. Rex L. Huff for suggestions concerning the presentation of data, and to Drs. R. H. Williams, Rex L. Huff, and Clement A. Finch for critical appraisal of the manuscript.

\section{APPENDIX}

\section{Details of patients with cirrhosis}

Case 11, E.N.: Male Age 69, KCH 68870, Studied June, 1951. Epidemic viral hepatitis 1925. Non-alcoholic. Admitted KCH May, 1950 for massive upper gastro-intestinal hemorrhage. Initially, clinical criteria of cirrhosis absent. Surgical exploration revealed cirrhosis, portal hypertension, esophageal varices; splenic artery ligated. Hemorrhage recurred followed by ascites. After improvement, direct porta-caval shunt accomplished September, 1950; thereafter continuously hospitalized in chronic disease unit, where study was conducted.

Case 12, P.V.: Male, Age 58, KCH 118138, Studied June, 1951. Moderate wine intake for many years. In 1949 noted abdominal swelling. First $\mathrm{KCH}$ admission June, 1950 with spider angiomata, marked hepatic dysfunction. Needle liver biopsy March, 1951: advanced portal cirrhosis. Second KCH admission May, 1951 for anorexia and jaundice; following convalescence in chronic disease unit, transferred to Metabolic Research Ward.

Case 13, F.E.: Male, Age 51, KCH 274770, Studied January, 1952. Bar-tender with moderate, steady alcohol intake for many years. Jaundice in October, 1950. In December, 1950, onset of ascites requiring two paracenteses. First $\mathrm{KCH}$ admission February, 1951 with ascites, right hydrothorax, peripheral edema, hepatomegaly. Following interval care in Out-Patient Gastrointestinal Clinic, readmitted December, 1951 with ascites, right hydrothorax, peripheral edema, hepatomegaly, splenomegaly. After diuresis, transferred to Metabolic Research Ward for study.

Case 14, H.H.: Male, Age 48, $\mathrm{KCH}$ 234187, Studied April, 1953. Prolonged, large intake of alcohol, especially after 1943. First jaundiced 1937. Hospitalized in Minneapolis, Minn. 1946 for jaundice. In 1949, prolonged hospitalization in University Hospitals, Iowa City, Iowa with findings of jaundice, spider angiomata, peripheral edema, hepatomegaly. Liver biopsy : portal cirrhosis. First $\mathrm{KCH}$ admission November, 1952 with findings of spider angiomata, hepatomegaly, splenomegaly, ascites; following prolonged convalescence in chronic disease unit, transferred to Metabolic Research Ward.

Case 15, A.K.: Male, Age 52, KCH 303167, Studied June, 1953. Large alcoholic consumption for 30 years. In 1952 noted gradual abdominal swelling. Admitted $\mathrm{KCH}$ March, 1953 with jaundice, ascites, right hydrothorax, peripheral edema, spider angiomata, hepatomegaly, splenomegaly. After convalescence in chronic disease unit, transferred to Metabolic Research Ward.

Case 16, R.L.: Female, Age 40, KCH 301438, Studied October, 1953. Large alcohol intake for 10 years. Hospitalized 1952 for nausea, anorexia, hepatomegaly. First admitted KCH January 1953 with delirium tremens; findings included menorrhagia, jaundice, hepatomegaly, spider angiomata, ascites. Readmitted KCH September, 1953 with ascites, edema, hepatomegaly, splenomegaly. Convalescence continued in chronic disease unit, from which patient was transferred to Metabolic Research Ward.

Case 17, W.H.: Male, Age 51, KCH 223754, Studied January, 1954. Large alcohol intake for 15 years. Recurring jaundice 8 years. Five KCH admissions between 1948 and 1953 for jaundice, delirium tremens, edema, hepatic coma. Continuously hospitalized after September, 1953 with transfer from chronic disease unit to Metabolic Research Ward.

Case 18, C.S.: Male, Age 40, $\mathrm{KCH} 263080$, Studied May, 1954. Merchant seaman with steady alcohol intake since age 19, increased after age 27 . First jaundice 1948. Entered Marine Hospital, Seattle, 1949 with jaundice; diagnosis of portal cirrhosis made. First $\mathrm{KCH}$ admission 1951 with jaundice, ascites, peripheral edema, and hepatomegaly. Needle liver biopsy on admission: subacute fatty cirrhosis. Repeat biopsy four weeks later: satisfactory parenchymal repair, considerable fibrosis. Readmitted to $\mathrm{KCH}$ January, 1954, with recurrent ascites, jaundice, upper gastro-intestinal hemorrhage of 
undetermined source; following prolonged convalescence in chronic disease unit, transferred to Metabolic Research Ward.

\section{REFERENCES}

1. Steinbock, H. L., and Tarver, H., Plasma protein. V. The effect of the protein content of the diet on turnover. J. Biol. Chem., 1954, 209, 127.

2. Lever, W. F., Gurd, F. R. N., Uroma, E., Brown, R. K., Barnes, B. A., Schmid, K., and Schultz, E. L., Chemical, clinical, and immunological studies on the products of human plasma fractionation. XL. Quantitative separation and determination of the protein components in small amounts of normal human plasma. J. Clin. Invest., 1951, 30, 99.

3. Surgenor, D. M., Alexander, B., Goldstein, R., and Schmid, K., A system for the separation of the protein components of human plasma. II. The components of the clotting process. J. Phys. \& Colloid Chem., 1951, 55, 94.

4. Batchelor, W. H., and Brown, R. K., Personal communication.

5. Lindgren, F. T., Elliott, H. A., and Gofman, J. W., The ultracentrifugal characterization and isolation of human blood lipids and lipoproteins, with applications to the study of atherosclerosis. J. Phys. \& Colloid Chem., 1951, 55, 80.

6. Russ, E. M., Personal communication.

7. Kunkel, H. G., and Slater, R. J., Zone electrophoresis in a starch supporting medium. Proc. Soc. Exper. Biol. \& Med., 1952, 80, 42.

8. Moore, D. H., and White, J. U., A new compact Tiselius electrophoresis apparatus. Rev. Scient. Instruments, 1948, 19, 700.

9. Oncley, J. L., Gurd, F. R. N., and Melin, M., Preparation and properties of serum and plasma proteins. XXV. Composition and properties of human serum $\beta$-lipoprotein. J. Am. Chem. Soc., 1950, 72, 458.

10. Russ, E. M., Eder, H. A., and Barr, D .P., Proteinlipid relationships in human plasma. I. In normal individuals. Am. J. Med., 1951, 11, 468.

11. Gofman, J. W., Jones, H. B., Lindgren, F. T., Lyon, T. P., Elliott, H. A., and Strisower, B., Blood lipids and human atherosclerosis. Circulation, 1950, 2, 161.

12. Sperry, W. M., and Webb, M., A revision of the Schoenheimer-Sperry method for cholesterol determination. J. Biol. Chem., 1950, 187, 97.

13. Whitehorn, J. C., A method for the determination of lipoid phosphorus in blood and plasma. J. Biol. Chem., 1924, 62, 133.

14. Fiske, C. H., and Subbarow, Y., The colorimetric determination of phosphorus. J. Biol. Chem., 1925, 66, 375.

15. Morrison, P. R., Preparation and properties of serum and plasma proteins. XV. Some factors influencing the quantitative determination of fibrinogen. $\mathrm{J}$. Am. Chem. Soc., 1947, 69, 2723.
16. Pirie, N. W., Studies in the sulphur metabolism of the dog. XI. The metabolism of methionine and related sulphides. Biochem. J., 1932, 26, 2041.

17. Fiske, C. H., The determination of inorganic sulfate, total sulfate, and total sulfur in urine by the benzidine method. J. Biol. Chem., 1921, 47, 59.

18. Tarver, H., and Schmidt, C. L. A., The conversion of methionine to cystine: Experiments with radioactive sulfur. J. Biol. Chem., 1939, 130, 67.

19. Kinsell, L. W., Margen, S., Tarver, H., Frantz, J. McB., Flanagan, E. K., Hutchin, M. E., Michaels, G. D., and McCallie, D. P., Studies in methionine metabolism. III. The fate of intravenously administered $S^{25}$-labeled-methionine in normal adult males, in patients with chronic hepatic disease, "idiopathic" hypoproteinemia and Cushing's syndrome. J. Clin. Invest., 1950, 29, 238.

20. Calvin, M., Heidelberger, C., Reid, J. C., Tolbert, B. M., and Yankwich, P. F., Isotopic Carbon. Techniques in its Measurement and Chemical Manipulation. New York, John Wiley, 1949, pp. 296, 288.

21. Gibson, J. G., 2nd, and Evans, W. A., Jr., Clinical studies of the blood volume. I. Clinical application of a method employing the azo dye "Evans blue" and the spectrophotometer. J. Clin. Invest., 1937, 16, 301.

22. Hiller, A., Plazin, J., and Van Slyke, D. D., A study of conditions for Kjeldahl determination of nitrogen in proteins. Description of methods with mercury as catalyst, and titrimetric and gasometric measurements of the ammonia formed. J. Biol. Chem., 1948, 176, 1401.

23. Kirk, P. L., A one-piece glass micro-Kjeldahl distillation apparatus. Indust. Engin. Chem., Anal. Ed., 1936, 8, 223.

24. Folin, O., Laboratory Manual of Biological Chemistry, 5th Ed., New York, D. Appleton-Century, 1934, p. 271.

25. Reinhold, J. G., Steward, V., and Gilman, L. D., Separation of serum albumin from globulin by means of sodium sulfate-sulfite solutions. Abstr. Pap., Am. Chem. Soc., 1950, 117th meeting, p. 15C.

26. Reinhold, J. G., Total protein, albumin, and globulin in Standard Methods of Clinical Chemistry, Reiner, M., Ed., New York, Academic Press, Inc., 1953, vol. I., pp. 88-97.

27. Ratnoff, O. D., and Menzie, C., A new method for the determination of fibrinogen in small samples of plasma. J. Lab. \& Clin. Med., 1951, 37, 316.

28. Lowry, O. H., Rosebrough, N. J., Farr, A. L., and Randall, R. J., Protein measurement with the Folin phenol reagent. J. Biol. Chem., 1951, 193, 265.

29. Miller, L. L., Bale, W. F., Yuile, C. L., Masters, R. E., Tisakoff, G. H., and Whipple, G. H., The use of radioactive lysine in studies of protein metabolism. Synthesis and utilization of plasma proteins. J. Exper. Med., 1949, 90, 297. 
30. London, I. M., Studies on the rates of formation of serum proteins in man in Symposia on Nutrition, Vol. II. Plasma Proteins, Youmans, J. B., Ed., Springfield, Charles C Thomas, 1950, pp. 72-82.

31. Tarver, H., The metabolism of amino acids and proteins in Amino Acids and Proteins. Theory, Methods, Application, Greenberg, D. M., ed., Springfield, Charles C Thomas, 1951, pp. 769-908.

32. Forker, L. L., and Chaikoff, I. L., Turnover of serum proteins in diabetes as studied with $\mathrm{S}^{25}$ labeled proteins. J. Biol. Chem., 1952, 196, 829.

33. Schoenberger, J. A., Kroll, G., Sakamoto, A., and Kark, R. M., Investigation of the permeability factor in ascites and edema using albumin tagged with I'12. Gastroenterology, 1952, 22, 607.

34. Berson, S. A., Yalow, R. S., Schreiber, S. S., and Post, J., The distribution and fate of intravenously administered $I^{13}$ labeled human serum albumin. J. Clin. Invest., 1953, 32, 554.

35. Kunkel, H. G., and Tiselius, A., Electrophoresis of proteins on filter paper. J. Gen. Physiol., 1951, 35, 89.

36. Wolfson, W. Q., Cohn, C., Calvary, E., and Ichiba, F., Studies in serum proteins. V. A rapid procedure for the estimation of total protein, true albumin, total globulin, alpha globulin, beta globulin and gamma globulin in $1.0 \mathrm{ml}$. of serum. Am. J. Clin. Path., 1948, 18, 723.

37. Tarver, H., and Reinhardt, W. O., Methionine labeled with radioactive sulfur as an indicator of protein formation in the hepatectomized dog. J. Biol. Chem., 1947, 167, 395.

38. Lee, N. D., Anderson, J. T., Miller, R., and Williams, R. H., Incorporation of labeled cystine into tissue protein and subcellular structures. J. Biol. Chem., 1951, 192, 733.

39. Peterson, E. A., and Greenberg, D. M., Characteristics of the amino acid-incorporating system of liver homogenates. J. Biol. Chem., 1952, 194, 359.

40. Schöberl, A., Eine neue Methode zur Einführung von Schwefelin Eiweitzstaffe. Angew. Chem., 1948, A60, 7.

41. Bettelheim, F. R., Tyrosine-o-sulfate in a peptide from fibrinogen. J. Am. Chem. Soc., 1954, 76, 2838.

42. Humphrey, J. H., and McFarlane, A. S., Rate of elimination of homologous globulins (including antibody) from the circulation. Biochem. J., 1954, 57, 186.

43. Volwiler, W., Goldsworthy, P. D., MacMartin, M. P., Wood, P. A., Mackay, I. R., Fremont-Smith, K., and Shook, D. F., Turn-over rates of various plasma proteins in normal and cirrhotic humans using biosynthetic methods. J. Clin. Invest., 1954, 33, 970.

44. Madden, R. E., and Gould, R. G., The turnover rate of fibrinogen in the dog. J. Biol. Chem., 1952, 196, 641.

45. Armstrong, S. H., Jr., McLeod, K., Wolter, J., and Kukral, J., The persistence in the blood of the radioactive label of albumin, gamma globulins, globulins of intermediate mobility studied with $\mathrm{S}^{25}$ and paper electrophoresis: Methods and preliminary results. J. Lab. \& Clin. Med., 1954, 43, 918.

46. Margen, S., and Tarver, H., Studies in human plasma protein formation. II. Fate of transfused internally $\mathrm{S}^{25}$ labeled plasma protein and albumin, compared with $I^{120}$ labeled albumin, and plasma protein endogenously synthesized from $S^{25}$ labeled amino acid precursors. Proc. Eighth Annual Meeting Western Society for Clinical Research, Carmel, Calif., January 28-29, 1955.

47. Margen, S., and Tarver, H., Personal communication. 48. Armstrong, S. H., Jr., Kukral, J., Hershman, J., McLeod, K., and Wolter, J., Comparison of the persistence in the blood of gamma globulins labeled with $S^{35}$ and $I^{131}$ in the same subjects. J. Lab. \& Clin. Med., 1954, 44, 762.

49. Vaughan, J. H., Armato, A., Goldthwaite, J., Brachman, P., Favour, C. B., and Bayles, T. B., Fate of intravenously injected labelled gamma globulin in the normal subject and in patients with rheumatoid arthritis. J. Clin. Invest., 1952, 31, 668.

50. Myant, N. B., Observations on the metabolism of human gamma globulin labelled by radioactive iodine. Clin. Sc., 1952, 11, 191.

51. Dixon, F. J., Talmage, D. W., Maurer, P. H., and Deichmiller, M., The half-life of homologous gamma globulin (antibody) in several species. J. Exper. Med., 1952, 96, 313.

52. Eisenmenger, W. J., and Slater, R. J., Distribution and decay of $I^{m}$ tagged albumin and gamma globulin in patients with cirrhosis. J. Clin. Invest., 1953, 32, 564.

53. Havens, W. P., Jr., Dickensheets, J., Bierly, J. N., and Eberhard, T. P., The half-life of normal human gamma globulin in patients with hepatic cirrhosis. J. Clin. Invest., 1953, 32, 573.

54. Gabrieli, E. R., Goulian, D., Jr., Kinersly, T., and Collet, R., Zone paper electrophoresis studies on radio-iodinated human serum albumin. $\mathrm{J}$. Clin. Invest., 1954, 33, 136.

55. Li, C. H., Simpson, M. E., and Evans, H. M., Iodination of hypophyseal growth hormone. J. Biol. Chem., 1948, 176, 843.

56. Fraenkel-Conrat, J., and Fraenkel-Conrat, H., The essential groups of insulin. Biochem. et Biophys. Acta, 1950, 5, 89.

57. Kallee, E., and Seybold, G., Uber 131-J-signiertes insulin. III. Verteilung im rattenorganismus. Ztschr. Naturforsch., 1954, 9b, 307.

58. Gitlin, D., Light scattering and ultracentrifugation methods in studies of precipitin systems and their application to human metabolism in Serological Approaches to Studies of Protein Structure and Metabolism. Cole, W. H., Editor, New Brunswick, N. J., Rutgers Univ. Press, 1954, pp. 23-27. 
59. Miller, L. L., and Bale, W. F., Synthesis of all plasma protein fractions except gamma globulins by the liver. The use of zone electrophoresis and lysine- $\epsilon-\mathrm{C}^{14}$ to define the plasma proteins synthesized by the isolated perfused liver. J. Exper. Med., 1954, 99, 125.

60. Miller, L. L., Bly, C. G., and Bale, W. F., Plasma and tissue proteins produced by non-hepatic rat organs as studied with lysine-e-C ${ }^{44}$. Gamma globulins the chief plasma protein fraction produced by nonhepatic tissues. J. Exper. Med., 1954, 99, 133.

61. Armstrong, S. H., Jr., Budka, M. J. E., and Morrison, $K$. C., Preparation and properties of serum and plasma proteins. XI. Quantitative interpretation of electrophoretic Schlieren diagrams of normal human plasma proteins. J. Am. Chem. Soc., 1947, 69, 416.

62. Solomon, A. K., Equations for tracer experiments. J. Clin. Invest., 1949, 28, 1297.

63. Solomon, A. K., The kinetics of biological processes. Special problems connected with the use of tracers in Advances in Biological and Medical Physics, New York, Academic Press, Inc., 1953, vol. III, pp. 65-97.

64. Niklas, A., and Poliwoda, H., Zur Frage der biologischen Halbwertszeit menschlicher Albumine und Globuline. Biochem. Ztschr., 1954, 326, 97. 